\title{
CORRIENTES DEL CONSTITUCIONALISMO CONTEMPORÁNEO A DEBATE*
}

\author{
CONTEMPORARY CONSTITUTIONALISM UNDER DEBATE
}

\author{
Ana Micaela ALTERIO**
}

\section{Resumen:}

En este artículo compararé tres versiones diferentes del constitucionalismo en la teoría constitucional contemporánea: el así llamado neoconstitucionalismo(s), el constitucionalismo popular y el nuevo constitucionalismo latinoamericano. En particular, exploraré: las pretensiones normativas de cada teoría; los modelos de legitimidad democrática, sustantivos y procedimentales, que en mi opinión respaldan al neoconstitucionalismo y al constitucionalismo popular, respectivamente; la institucionalización del judicial review propuesta por cada teoria; las teorias de democracia que está implícitas en cada modelo, y, finalmente, cómo la relación entre el derecho constitucional y la politica es concebida.

\footnotetext{
* Artículo recibido el 26 de noviembre de 2012 y aceptado para su publicación el 7 de mayo de 2013.

** Máster y doctoranda en Estudios Avanzados en Derechos Humanos del Instituto de Derechos Humanos "Bartolomé de las Casas", Universidad Carlos III de Madrid; Diplomada del Centro de Estudios Políticos y Constitucionales, abogada por la Universidad Nacional de Cuyo, Argentina, micaalterio@yahoo.com

Una versión previa y más reducida de este artículo, circunscribiéndose a la comparación entre las corrientes neoconstitucionalista y del constitucionalismo popular, se encuentra publicada en Alterio, Ana Micaela y Niembro Ortega, Roberto, Constitucionalismo popular en Latinoamérica, México, Porrúa, 2013, pp. 35-70. Agradezco a Roberto Niembro Ortega los comentarios, sugerencias y la discusión que tanto ayudaron a la preparación de este trabajo.
}

PROBLEMA

Anuario de Filosofía y Teoría del Derecho, Núm. 8, enero-diciembre de 2014, pp. 227-306 
Esta revista forma parte del acervo de la Biblioteca Jurídica Virtual del Instituto de Investigaciones Jurídicas de la UNAM

ANA MICAELA ALTERIO

\title{
Palabras clave:
}

Teoría constitucional, neoconstitucionalismo, constitucionalismo popular, nuevo constitucionalismo latinoamericano, democracia.

\begin{abstract}
:
In this article I will compare different understandings of constitutionalism in contemporary constitutional theory: the so called neoconstitutionalism(s), popular constitutionalism and the new constitutionalism in Latin America. Specifically, I will explore the normative pretensions of each theory; the substantial and procedural models of democratic legitimacy that in my opinion support neoconstitutionalism, popular constitutionalism and new constitutionalism respectively; the institutionalization of judicial review proposed by each theory; the theories of democracy that are implicit in each model, and finally, how the relation between constitutional law and politics is conceived.
\end{abstract}

\section{Keywords:}

Constitutional Theory, Neoconstitutionalism, Popular Constitutionalism, the New Constitutionalism in Latin America, Democracy. 
Esta revista forma parte del acervo de la Biblioteca Jurídica Virtual del Instituto de Investigaciones Jurídicas de la UNAM www.juridicas.unam.mx

http://biblio.juridicas.unam.mx

CONSTITUCIONALISMO CONTEMPORÁNEO A DEBATE

SUMARIO: I. Introducción. II. Neoconstitucionalismo(s). III. El constitucionalismo popular. IV. El nuevo constitucionalismo latinoamericano. V. Pertinencia de la comparación. VI. Bibliografía.

\section{INTRODUCCIÓN}

El presente artículo tiene por objeto hacer una comparación entre algunas formas de abordar el constitucionalismo en el pensamiento contemporáneo, a saber las llamadas corrientes "neoconstitucionalista(s)", el "constitucionalismo popular" y el "nuevo constitucionalismo latinoamericano".

Varias aclaraciones deben hacerse ante este primer enunciado. Para empezar, ninguna de estas —que he llamado- corrientes es homogénea en su interior. De hecho podría decirse del neoconstitucionalismo, que la etiqueta es en buena medida un intento de racionalización post hoc del pensamiento de varios autores que comparten características comunes pero también muchas diferencias. ${ }^{1}$ Eso ha llevado a que se hable no de un neoconstitucionalismo sino de neoconstitucionalismos ${ }^{2}$ o a que se agreguen adjetivos calificativos a los términos, como por ejemplo neo-constitucio-

1 Ahumada, María Ángeles, "Neoconstitucionalismo y constitucionalismo" en Comanducci, Paolo, Ahumada, María Ángeles, González Lagier, Daniel, Positivismo jurídico y neoconstitucionalismo, Madrid, Fundación Coloquio Jurídico Europeo, 2009, p. 135. De hecho muchos de ellos no se reconocerian como parte de las propuestas a las que se los adscribe; en este sentido advierte una de las "creadoras" del término neoconstitucionalismo que el mismo fue pensado para un "objeto" identificado, reconstruido o inventado en el momento en que se lo nominó, un objeto de confines opacos y de difícil interpretación. Véase Pozzolo, Susanna, "Metacritica del neocostituzionalismo. Una risposta ai critici di 'Neocostituzionalismo e positivismo giuridico", Diritto \& questioni pubbliche, núm. 3, 2003, p. 52 .

2 Se suele utilizar el plural entre paréntesis para resaltar que no se puede hablar de "un" neoconstitucionalismo sino de varios, dado lo disímiles de muchas propuestas que se suelen enmarcar bajo esta sola etiqueta. Véase Carbonell, Miguel (ed.), Neoconstitucionalismo(s), Madrid, Trotta, 2003. 
Esta revista forma parte del acervo de la Biblioteca Jurídica Virtual del Instituto de Investigaciones Jurídicas de la UNAM www.juridicas.unam.mx

http://biblio.juridicas.unam.mx

ANA MICAELA ALTERIO

nalismo conceptual o normativo ${ }^{3}$ o constitucionalismo garantista. ${ }^{4}$ Algo similar ocurre con los constitucionalistas populares, ${ }^{5}$ que no siempre se reconocen bajo esta signatura o que marcan sus diferencias también con el uso de adjetivos del tipo constitucionalismo democrático o constitucionalismo popular mediado. ${ }^{7} \mathrm{Ni}$ hablar del llamado nuevo constitucionalismo latinoamericano que, aunque podría considerarse "un modelo teórico que tiene expresión -con modalidades distintas- en algunas realidades constitucionales, ${ }^{8}$ lo cierto es que su desarrollo se ha producido más bien "en el extrarradio de la academia, producto más de las

3 Según la clasificación de García Figueroa, Alfonso, Criaturas de la moralidad. Una aproximación neoconstitucionalista al derecho a través de los derechos, Madrid, Trotta, 2009, p. 18.

4 Según la denominación que otorga a su teoría Ferrajoli, Luigi, Principia Iuris. Teoría del derecho y de la democracia, t. I: Teoría del derecho, trad. de Perfecto Andrés Ibáñez, Juan Carlos Bayón, Marina Gascón, Luis Prieto Sanchís y Alfonso Ruiz Miguel, Madrid, Trotta, 2011.

5 Con respecto a las divergencias entre autores de constitucionalismo popular, véase Niembro, Roberto “¿Qué es el constitucionalismo popular? Una breve referencia al uso de las fuerzas armadas en México como fuerzas de seguridad", en Alterio, Ana Micaela y Niembro Ortega, Roberto (coords.) Constitucionalismo popular en Latinoamérica, México, Porrúa, 2013 pp. 3-33.

6 Que sostendrian, como parte del constitucionalismo popular, autores como Robert Post y Reva Siegel de los que me ocuparé infra.

7 Según la calificación que el propio Barry Friedman da a su teoría, la cual a mi criterio dista mucho de poder llamarse "popular" en primer término. Véase por ejemplo del autor "Mediated Popular Constitutionalism", Michigan Law Review, vol. 101, 2003.

8 Salazar Ugarte, Pedro, "El nuevo constitucionalismo latinoamericano (una perspectiva crítica)", en González Pérez, Luis Raúl y Valadés, Diego (coords.), El constitucionalismo contemporáneo. Homenaje a Jorge Carpizo, México, UNAM, 2013, pp. 345-387, p. 353, disponible en http:// biblio. juridicas.unam.mx/libros/7/3271/22.pdf; aunque el autor, siguiendo a Viciano Pastor y Martínez Dalmau, distingue el "nuevo constitucionalismo" como corriente teórica — a la que aquí aludo- del "nuevo constitucionalismo latinoamericano" como modelo constitucional con plasmación institucional en la realidad o "fenómeno constitucional". En este artículo utilizaré el término nuevo constitucionalismo latinoamericano indistintamente para referirme a la corriente teórica como al modelo institucional. 
Esta revista forma parte del acervo de la Biblioteca Jurídica Virtual del Instituto de Investigaciones Jurídicas de la UNAM www.juridicas.unam.mx

http://biblio.juridicas.unam.mx

CONSTITUCIONALISMO CONTEMPORÁNEO A DEBATE

reivindicaciones populares y de los movimientos sociales que de planteamientos teóricos coherentemente armados"9 y por tanto, también es muy diversa.

Por otro lado, el desarrollo de cada una de estas doctrinas se ha dado en contextos absolutamente diferentes. Así, mientras el llamado neoconstitucionalismo ha nacido a la luz de las experiencias jurídicas europeas de la segunda posguerra -aunque eso no ha sido óbice para que se valiera de autores de otras procedencias e incluso para que tenga una gran influencia sobre el pensamiento latinoamericano en particular - el constitucionalismo popular es de cuño netamente estadounidense $-\mathrm{y}$ dentro de éste, minoritario-. ${ }^{10}$ Por último, como su nombre lo indica, el nuevo constitucionalismo ha surgido en ciertos países de Latinoamérica y pretende ser además, un constitucionalismo "auténtico" (autóctono), que responda a los problemas propios de la región.

Estas características que prima facie parecieran hacer muy dificil una comparación, pueden disolverse si nos centramos no tanto en las bases culturales de estas corrientes o en su historia, cuanto en sus pretensiones normativas. ${ }^{11}$

9 Véase Viciano Pastor, Roberto y Martínez Dalmau, Rubén, "Fundamento teórico del nuevo constitucionalismo latinoamericano", en Viciano Pastor, Roberto (ed.), Estudios sobre el nuevo constitucionalismo latinoamericano, Valencia, Tirant Lo Blanch, 2012, p. 19.

10 Se suele señalar que su (re)surgimiento en la academia norteamericana se debió al activismo que ha realizado la segunda Corte Rehnquist. Véase Kramer, Larry, "Popular Constitutionalism, circa 2004", California Law Review, vol. 92, núm. 4, 2004, p. 960.

11 Lo que centraría este trabajo en una visión "general" del constitucionalismo según la definición de Waldron, Jeremy, "Constitutionalism: A Skeptical View", New York University Public Law and Legal Theory Working Papers, Paper 248, 2012, pp. 3-5. También del autor "The Core of the Case Against Judicial Review", The Yale Law Journal 115, 2006, p. 1352; donde explica: "What is needed is some general understanding, uncontaminated by the cultural, historical, and political preoccupations of each society". Lo que no quiere decir que el contexto cultural, histórico y político no sea importante o incluso determinante a la hora de pensar en aplicar las propuestas normativas a determinadas realidades. 
Esta revista forma parte del acervo de la Biblioteca Jurídica Virtual del Instituto de Investigaciones Jurídicas de la UNAM www.juridicas.unam.mx

http://biblio.juridicas.unam.mx

ANA MICAELA ALTERIO

En este sentido, lo que pretendo hacer en este trabajo es abstraer las ideas - a mi criterio- principales de cada corriente y reparar en las teorias subyacentes a las mismas. Es así que un análisis como el propuesto puede resultar útil a los efectos de pensar la disciplina para Latinoamérica.

\section{NEOCONSTitucionAlismo(s)}

Ante todo es necesario establecer qué entiendo por neoconstitucionalismo. Aquí seguiré la definición que dieran sus mentores de la escuela genovesa. ${ }^{12}$ Comanducci sostiene que el término "constitucionalismo" (y neoconstitucionalismo) vehicula dos significados. Por un lado, designa una teoría y/o una ideología y/o un método de análisis del derecho. ${ }^{13}$ Por otro lado designa en cambio, algunos elementos estructurales de un sistema jurídico y político, que son descritos y explicados por el (neo) constitucionalismo como teoría, o que satisfacen los requisitos del (neo) constitucionalismo como ideología. En esta segunda acepción designa un modelo constitucional, o sea, el conjunto de mecanismos normativos e institucionales, realizados en un sistema jurídico-político históricamente determinado, que limitan los

12 Esta escuela, integrada por Susanna Pozzolo, Mauro Barberis y Paolo Comanducci, entre otros, fue la que a fines de la década de los noventa acuñó la categoría para criticar algunas tendencias post-positivistas de la filosofia jurídica contemporánea. Véase Comanducci, Paolo, "Constitucionalización y neoconstitucionalismo", en Comanducci, Paolo et al., Positivismo jurídico y neoconstitucionalismo, cit., p. 87.

13 La calificación del neoconstitucionalismo como "teoría del derecho", no es pacífica. La discusión que se plantea se centra en la cuestión de si el abordaje hasta ahora predominante del positivismo jurídico (en cualquiera de sus múltiples acepciones) sigue siendo adecuado o más bien resulta estrecho o incluso estéril para hacer frente a las complejas estructuras normativas de los sistemas legales contemporáneos, como lo concibe el neoconstitucionalismo "conceptual", del que me ocuparé infra. Véase García Figueroa, Alfonso, Criaturas de la moralidad, cit., p. 18. 
Esta revista forma parte del acervo de la Biblioteca Jurídica Virtual del Instituto de Investigaciones Jurídicas de la UNAM www.juridicas.unam.mx

http://biblio.juridicas.unam.mx

CONSTITUCIONALISMO CONTEMPORÁNEO A DEBATE

poderes del Estado y/o protegen los derechos fundamentales. ${ }^{14}$

El constitucionalismo así surge con las constituciones de finales de siglo XVIII, pero es recién tras la segunda guerra mundial que habria cambiando sus rasgos característicos, al punto de configurar una nueva teoria que la doctrina coincide en llamar "neoconstitucionalismo(s)". ${ }^{15}$ Lo que en suma diferenciaría al constitucionalismo del neoconstitucionalismo, según Comanducci, sería que este último no se exhibe únicamente como ideología, sino también como una teoria que concurre (compite) con el positivismo. ${ }^{16}$

En este orden de ideas, caracteriza el tránsito del constitucionalismo al neoconstitucionalismo el fenómeno de la "constitucionalización del ordenamiento jurídico" que significa un proceso de desarrollo de las instituciones que satisface por lo menos siete condiciones: 1) rigidez de la constitución; 2) control de constitucionalidad de las leyes; 3) fuerza vinculante de la constitución; 4) "sobreinterpretación" de las disposiciones constitucionales; 5) aplicación directa de tales disposiciones por parte de los jueces; 6) interpretación conforme de la ley ordinaria; 7) influencia directa de la constitución en las relaciones políticas. ${ }^{17} \mathrm{De}$ alli se deriva que lo que

14 Comanducci, Paolo, "Formas de (neo)constitucionalismo: un análisis metateórico", en Carbonell, Miguel (ed.), Neoconstitucionalismo(s), cit., p. 75.

15 Aunque también es cierto que hay quienes consideran que el nacimiento del neoconstitucionalismo tuvo lugar con el ataque que en los años setenta del siglo XX emprendió Ronald Dworkin contra el positivismo jurídico. Véase Salazar Ugarte, Pedro, La democracia constitucional. Una radiografía teórica, México, Fondo de Cultura Económica-UNAM, Instituto de Investigaciones Jurídicas, 2006, nota al pie 56, p. 94; Barberis, Mauro, "Neoconstitucionalismo, democracia e imperialismo de la moral”, en Miguel Carbonell (ed.) Neoconstitucionalismo(s), cit., p. 260.

16 Comanducci, Paolo, "Formas de (neo)constitucionalismo: un análisis metateórico", cit., p. 83.

17 Guastini, Ricardo, "La 'constitucionalización' del ordenamiento jurídico: el caso italiano”, en Carbonell, Miguel (ed.), Neoconstitucionalismo(s), cit., pp. 49-57. Aunque el autor conceptualiza el fenómeno más allá del neoconstitucionalismo, son varios autores los que usan esta categoría 
Esta revista forma parte del acervo de la Biblioteca Jurídica Virtual del Instituto de Investigaciones Jurídicas de la UNAM www.juridicas.unam.mx

http://biblio.juridicas.unam.mx

ANA MICAELA ALTERIO

caracteriza al neoconstitucionalismo es que, directamente, hace suya la tesis iusnaturalista de la conexión (identificativa) necesaria entre derecho y moral, aunque se diferencia del iusnaturalismo tradicional y se acerca al iuspositivismo inclusivo, en cuanto sitúa tal conexión en el nivel de los principios fundamentales o constitucionales. ${ }^{18}$

Asi las constituciones, al haber incorporado toda una serie de valores, se convertirian en un objeto completamente diferente del derecho infra-constitucional: la constitución seria un valor en si en tanto positiviza un contenido de justicia. Esto la dotaría de una fuerza invasiva general (conocida también como efecto irradiación) ${ }^{19}$ que habría determinado el re-enlazamiento del vínculo entre derecho y moral, que estructuralmente se pondría en evidencia con la posición subordinada de la ley en el sistema de fuentes. ${ }^{20}$

Pero no todos están de acuerdo con dicha conclusión. Luigi Ferrajoli es uno de los autores que se ha dedicado en forma profunda al estudio de estos fenómenos que, según su particular concepción, no significan que haya una vinculación entre derecho y moral, sino que implican una refundación jurídica del derecho y de las instituciones políticas, fruto de las duras lecciones impartidas por las tragedias de la de primera mitad del siglo pasado. ${ }^{21}$ Nos

para caracterizar al neoconstitucionalismo. Para una postura contraria, notando las falencias de este concepto para dar cuenta del neoconstitucionalismo véase Cruz, Luis M., Estudios sobre el neoconstitucionalismo, México, Porrúa, 2006, p. 4.

18 Barberis, op. cit., pp. 263 y 264.

19 Prieto Sanchís, Luis, "Principia iuris: una teoría del derecho no (neo) constitucionalista para Estado constitucional", Doxa, Cuadernos de Filosofía del Derecho, núm. 31, Madrid, Marcial Pons, 2008, p. 341.

20 Pozzolo, Susanna, "Un constitucionalismo ambiguo", en Carbonell, Miguel (ed.), Neoconstitucionalismo(s), cit., p. 188.

21 Ferrajoli, Luigi, Democracia y garantismo, Carbonell, Miguel (ed.), Madrid, Trotta, 2008, p. 304. Es por esta diferencia y otras relativas a la estructura de las normas, los métodos de interpretación, etcétera, que Ferrajoli no se considera un neoconstitucionalista, sino más bien se dedica a criticar a esta teoría desde la teoría garantista. De todos modos colo-

PROBLEMA

Anuario de Filosofia y Teoría del Derecho, Núm. 8, enero-diciembre de 2014, pp. 227-306 
Esta revista forma parte del acervo de la Biblioteca Jurídica Virtual del Instituto de Investigaciones Jurídicas de la UNAM www.juridicas.unam.mx

http://biblio.juridicas.unam.mx

CONSTITUCIONALISMO CONTEMPORÁNEO A DEBATE

dice el autor que a partir de la difusión en Europa, tras la Segunda Guerra Mundial, de las constituciones rígidas y del control de constitucionalidad de las leyes ordinarias ${ }^{22}$ se habría generado un cambio de modelo normativo, que él denomina "modelo neo-iuspositivista" del Estado Constitucional de Derecho. ${ }^{23}$

Según Ferrajoli el nuevo paradigma constitucional viene a caracterizarse por "la sujeción a la ley de la propia ley, no sólo en cuanto a las formas de los actos que la producen, sino también en cuanto a los contenidos normativos producidos por ellos. Esta sujeción ha tenido lugar a través de la incorporación, en constituciones rígidas, de principios ético-politicos [...] transformados, de fuentes de legitimación política o externa en fuentes de legitimación (y si son violados, de deslegitimación) también jurídica o interna". ${ }^{24}$ Así, "el derecho ya no regula sólo su 'ser' sino también su 'deber ser'; no programa sólo los comportamientos humanos sino que también se proyecta a sí mismo, vinculándose a opciones positivas (de hacer) y negativas (de no hacer) en garantía de los derechos fundamentales; ya no se funda sólo sobre el principio autoritas, non veritas facit legem, sino que

co al autor dentro de este capítulo puesto que las similitudes entre ambas teorias, sobre todo en los puntos que aqui se analizan como fundamentales, son patentes, aunque iré marcando las diferencias cuando sean relevantes.

22 He de insistir en que estos rasgos ya se encontraban en algunas constituciones previas a la segunda gran guerra, por ejemplo piénsese en Europa en el Tribunal Constitucional austríaco, o en - con sus grandes diferencias - el modelo norteamericano; pero lo que haría que se hable de un cambio de paradigma sería la reunión de todos estos elementos funcionando al mismo tiempo. Esto es subrayado por Carbonell, Miguel, Neoconstitucionalismo y derechos fundamentales, Quito, Cevallos, 2010, p. 30 .

23 En contraposición al modelo anterior (o paleo-iuspositivista) que corresponde al Estado legislativo de derecho (o Estado legal) y que surgió con el nacimiento del Estado moderno como monopolio de la producción jurídica. Ferrajoli, Luigi, "Pasado y futuro del Estado de derecho", en Carbonell, Miguel (ed.), Neoconstitucionalismo(s) cit., p.14.

24 Ferrajoli, Luigi, Principia Iuris, cit., pp. 25, 38. 
Esta revista forma parte del acervo de la Biblioteca Jurídica Virtual del Instituto de Investigaciones Jurídicas de la UNAM www.juridicas.unam.mx

http://biblio.juridicas.unam.mx

ANA MICAELA ALTERIO

también sobre el principio de la coherencia, y por lo tanto de la veritas que lógicamente debe caracterizar el juicio de compatibilidad de las normas de grado inferior con las de grado superior. Y se lleva a cabo por consiguiente, a través de los vínculos de forma y de contenido impuestos a su producción, la superación de la vieja dicotomía expresada por los pares auctoritas/veritas y 'racionalidad formal'/'racionalidad sustancial' con la que normalmente se formula la oposición entre paradigma iuspositivista y paradigma iusnaturalista". 25

Así el autor italiano sostiene que ha ocurrido un cambio de paradigma "revolucionario" 26 en tanto afecta, no sólo el papel del derecho y las condiciones de validez de las leyes, sino también el papel de la jurisdicción (afectando la relación juez-ley) el papel de la ciencia jurídica y la naturaleza de la democracia. Especialmente, con respecto al nuevo papel del juez, Ferrajoli explica que justamente la sujeción a la constitución lo transforma en garante de los derechos fundamentales, incluso frente al legislador, a través de la censura de la invalidez de las leyes y demás actos del poder político que puedan violar aquellos derechos. ${ }^{27}$ Pues bien, hay acuerdo entre los autores que estudian esta corriente en que ésta es una de las señas de identidad del neoconstitucionalismo, que ya no solo gira en torno a los derechos,

25 Ibidem, p. 463. Cabe aclarar que la teoría de Ferrajoli, al ser una teoría formal no nos dice nada respecto a cuáles sean o deban ser estos contenidos, sólo nos dice que si son proclamados de modo universal, serán considerados derechos fundamentales (ibidem, pp. 684-689), quedarán sustraídos de las decisiones políticas y por ello determinarán límites y vínculos a la política. Lo que es lo mismo que decir que los derechos fundamentales circunscriben la llamada esfera de lo indecidible. Ibidem, pp. 774 y 775 .

26 En igual sentido Zagrebelsky, considera este "cambio de paradigma" como un verdadero cambio genético. Véase Zagrebelsky, Gustavo, El derecho dúctil. Ley, derechos, justicia, 8a. ed., trad. de Marina Gascón, Madrid, Trotta, 2008, p. 33.

27 Ferrajoli, Luigi, Democracia y garantismo, cit., p. 211, también en Derechos y garantías. La ley del más débil, 5a. ed., trad. de Andrés Perfecto Ibáñez y Andrea Greppi, Madrid, Trotta, 2006, p. 26. 
Esta revista forma parte del acervo de la Biblioteca Jurídica Virtual del Instituto de Investigaciones Jurídicas de la UNAM www.juridicas.unam.mx

http://biblio.juridicas.unam.mx

CONSTITUCIONALISMO CONTEMPORÁNEO A DEBATE

sino que también al hecho de que su aplicación se encuentra encomendada a los jueces. ${ }^{28}$

A esta altura el lector o la lectora ya habrá podido advertir cierta disonancia entre las formas de abordaje presentadas por los distintos autores citados como neoconstitucionalistas. Así, para algunos (principalmente Ferrajoli) lo que ha cambiado con respecto al paradigma anterior es el objeto de estudio (las constituciones se han modificado a partir de la segunda mitad del siglo XX) ${ }^{29}$ pero no por ello debe cambiarse el método para abordarlo. Así visto, aún sería útil el positivismo jurídico al momento de entender las constituciones actuales y también el Estado constitucional que forjan. A este conjunto de autores, Garcia Figueroa los clasifica como neoconstitucionalistas normativos, que serían —según él- insuficientemente neoconstitucionalistas o neoconstitucionalistas en sentido débil. ${ }^{30}$ Éstos se carac-

28 Prieto Sanchís, Luis, "El constitucionalismo de los derechos", Teoría del neoconstitucionalismo. Ensayos escogidos, Madrid, Trotta-UNAM, Instituto de Investigaciones jurídicas, 2007, p. 215. Para este autor el neoconstitucionalismo es el resultado de la convergencia de dos tradiciones constitucionales que han caminado separadas, reuniendo un fuerte contenido normativo de la una y una garantía jurisdiccional y correlativa desconfianza ante el legislador, de la otra. El resultado se ve en "una Constitución transformadora que pretende condicionar de modo importante las decisiones de la mayoría, pero cuyo protagonismo fundamental no corresponde al legislador, sino a los jueces", en "Neoconstitucionalismo y ponderación judicial", en Carbonell, Miguel (ed.), Neoconstitucionalismo(s), cit., pp. 124-127. En igual sentido el autor en Justicia constitucional y derechos fundamentales, Madrid, Trotta, 2003, pp. 107 y ss.

29 Aunque esta afirmación es bastante controvertida. De hecho, se resalta que lo que daría cuenta de la "evolución" que desemboca en el Estado constitucional no sería tanto un cambio estructural en los sistemas jurídico-políticos (como la constitución normativa y rígida) sino el componente de valor, que implica una constitución como ideología. Véase Aguiló Regla, Josep, "Sobre las contradicciones (tensiones) del constitucionalismo y las concepciones de la constitución", en Carbonell, Miguel y García Jaramillo, Leonardo (eds.), El canon neoconstitucional, Madrid, Trotta, 2010, p. 247.

30 García Figueroa, Alfonso, Criaturas de la Moralidad, cit., p. 18. 
Esta revista forma parte del acervo de la Biblioteca Jurídica Virtual del Instituto de Investigaciones Jurídicas de la UNAM www.juridicas.unam.mx

http://biblio.juridicas.unam.mx

ANA MICAELA ALTERIO

terizarian por definir una política del derecho que es antiformalista y antilegalista pero positivista.

Pero están quienes consideran que habiendo cambiado el objeto de investigación, es necesario un cambio radical de metodologia. Las nuevas constituciones, que se distinguirían en cuanto a su contenido por la incorporación de una serie de valores morales; y por su forma, en cuanto que sus preceptos se expresan más a través de principios que bajo la apariencia de reglas; 31 harian obsoleto al positivismo jurídico, incapaz de explicarlas. ${ }^{32}$ Así, esta evolución histórica ${ }^{33}$ habría significado también una modificación sustancial para la teoría del derecho, afectando su concepto mismo. Dentro de este entendimiento mayoritario, se encuentran autores como Dworkin, Alexy, Zagrebelsky, Atienza o Ruiz Manero, ${ }^{34}$ a los que se clasifica como neo-constitucionalistas propiamente dichos o, en la nueva terminología de García Figueroa, "neoconstitucionalistas conceptuales". ${ }^{35}$ Sintéticamente se trata de una perspectiva iusfilosófica constitucionalista (en el sentido de insertarse en la corrien-

31 García Figueroa, Alfonso, Principios y positivismo jurídico, Madrid, Centro de Estudios Politicos y Constitucionales, 1998, p. 61.

32 Véase Atienza, Manuel, "Argumentación y Constitución", en Aguiló Regla, Josep et al., Fragmentos para una teoría de la Constitución, Madrid, Iustel, 2007, pp. 116, 127; también el autor en "Imperio de la ley y constitucionalismo. Un diálogo entre Manuel Atienza y Francisco Laporta”, El Cronista del Estado Social y Democrático de Derecho, núm. 0, 2008, p. 50.

33 Aunque hay autores como Atria que consideran que el neoconstitucionalismo ha significado una involución hacia formas legales pre-modernas. Atria, Fernando, "La ironía del positivismo jurídico", Doxa, Cuadernos de Filosofía del Derecho, núm. 27, Madrid, Marcial Pons, 2004, p. 83. Lo mismo opina Ferrajoli en relación al neoconstitucionalismo asociado a la ponderación de principios. Ferrajoli, Luigi, "Costituzionalismo principialista e costitucionalismo garantista", Giurisprudenza costituzionale, vol. 55, núm. 03, Milán, Giuffrè, 2010, p. 2816.

34 Para una distinción entre estos dos tipos de "neoconstitucionalismo" véase Ferrajoli, Luigi y Ruiz Manero, Juan, Dos modelos de constitucionalismo. Una conversación, Madrid, Trotta, 2012.

35 García Figueroa, Alfonso, Criaturas de la moralidad, cit., p. 18. 
Esta revista forma parte del acervo de la Biblioteca Jurídica Virtual del Instituto de Investigaciones Jurídicas de la UNAM www.juridicas.unam.mx

http://biblio.juridicas.unam.mx

CONSTITUCIONALISMO CONTEMPORÁNEO A DEBATE

te iusfilosófica dedicada a la formulación y predisposición de los límites jurídicos al poder político) y antipositivista. ${ }^{36}$

Lo cierto, y que aquí me interesa destacar, es que lo que subyace en común a estas posiciones es: (1) su afiliación a modelos de legitimidad (legal) fuertemente sustancialistas; lo que repercute en (2) los arreglos institucionales propuestos; asimismo, (3) en la teoría de la democracia que suponen y (4) en la relación que establecen entre derecho y politica. Abordaré por puntos estos temas, aunque por razones de espacio no pueda ahondar demasiado en cada uno.

\section{El modelo sustancialista de legitimidad}

Los modelos sustancialistas de legitimidad a los que aludo se enmarcan dentro de una vieja dicotomía entre contenido o resultado de las decisiones y forma o procedimiento a través del cual se toman éstas, decantándose por la primera de las alternativas. Así, según Zurn, el sustancialismo presenta la legitimidad de las decisiones democráticas como derivada de unos límites morales establecidos con anteriori$\operatorname{dad}^{37} \mathrm{o}$, en otras palabras, justifica el resultado de un proceso de toma de decisiones sólo si se corresponde con ciertos ideales que son lógicamente independientes del proceso empleado.

En el seno de los actuales Estados constitucionales, la tensión entre modelos se presenta en términos de constitucionalismo y democracia, aunque no de modo excluyente sino más bien como modelos mixtos ${ }^{38}$ o débiles. Así, el sustancialismo "débil" 39 parte de reconocer el valor irrenuncia-

\footnotetext{
36 Pozzolo, Susanna, "Un Constitucionalismo ambiguo", en Carbonell, Miguel (ed.), Neoconstitucionalismo(s), cit., p. 188.

37 Zurn, Christorpher F., "Deliberative democracy and constitutional review", Law and Philosophy, núm. 21, Kluwer Law International, 2002, p. 476.

38 Ibidem, pp. 477-479.

39 Según el esquema de Linares, Sebastián, La (i)legitimidad democrática del control judicial de las leyes, Madrid, Marcial Pons, 2008, pp. 30 y ss.
} 
Esta revista forma parte del acervo de la Biblioteca Jurídica Virtual del Instituto de Investigaciones Jurídicas de la UNAM www.juridicas.unam.mx

http://biblio.juridicas.unam.mx

ANA MICAELA ALTERIO

ble de ambas dimensiones, por lo que una decisión politica será legítima en tanto y en cuanto sea tomada mediante un procedimiento legitimo y respete ciertos criterios de justicia sustantiva. Así todo, la nota que caracteriza a esta postura es que considera que los derechos fundamentales (generalmente recogidos en constituciones y como contenido de las decisiones) deben efectivamente limitar el procedimiento democrático, por lo que en caso de tensión, se prioriza la dimensión sustantiva sobre la procedimental.

Este es el punto de partida que encontramos en el neoconstitucionalismo y que -incluso a su pesar - lo acerca a teorias iusnaturalistas. Así por ejemplo para Dworkin los derechos fundamentales son "triunfos" 40 que deben hacerse valer incluso frente a las decisiones democráticas (o contra las mayorías). ${ }^{41}$ En similar sentido Ferrajoli, como anticipé, considera que los derechos fundamentales plasmados en las constituciones constituyen la "esfera de lo indecidible"42 o, según la visión de Garzón Valdés, conforman "un coto vedado"43 para la democracia. Este último autor es bien claro al explicar que en el "coto vedado" han de resguardarse los derechos fundamentales no negociables, condición necesaria de la democracia representativa y que sólo fuera de este "coto vedado" cabe el disenso, la negociación y la tolerancia. Por ello — continúa el autor- quien pretenda abrir la puer-

40 Dworkin, Ronald, "Rights as Trumps", en Waldron, Jeremy (ed.), Theories of Rights, Nueva York, Oxford University Press, 1984, pp. 153-167.

41 Dworkin, Ronald, Los derechos en serio, trad. de Marta Guastavino, Barcelona, Ariel Derecho, 2002, pp. 37, 289.

42 Con sus palabras, la esfera de lo indecidible se trata del "conjunto de principios que, en democracia, están sustraídos a la voluntad de las mayorias". Ferrajoli, Luigi, Democracia y garantismo, cit., p. 102. Para una crítica a este concepto, me permito remitir a un trabajo anterior: Alterio, Ana Micaela, "La "esfera de lo indecidible" en el constitucionalismo de Luigi Ferrajoli: un análisis crítico", Universitas. Revista de Filosofía, Derecho y Política, núm. 13, enero de 2011.

43 Garzón Valdés, Ernesto, "Consenso, racionalidad y legitimidad" (1990), Derecho, ética y politica, Madrid, Centro de Estudios Políticos y Constitucionales, 1993, p. 469. 
Esta revista forma parte del acervo de la Biblioteca Jurídica Virtual del Instituto de Investigaciones Jurídicas de la UNAM www.juridicas.unam.mx

http://biblio.juridicas.unam.mx

CONSTITUCIONALISMO CONTEMPORÁNEO A DEBATE

ta del "coto vedado" y transformar derechos fundamentales en objeto de disenso y negociación, ${ }^{44}$ elimina la posibilidad de que la democracia pueda satisfacer la pauta de corrección moral que de ella se espera. ${ }^{45}$

Lo que ocurre es que, como hace explícito Bayón, este criterio no resulta realmente útil a los efectos de la toma de decisiones puesto que una decisión no será final por ser justa, sino porque es tomada por el actor al que se le dio el poder de tomarla en última instancia:

el constitucionalismo no consistiría - como suele decirseen un procedimiento de decisión con restricciones sustantivas, sino en una combinación de procedimientos, ensamblados de tal modo que algunos de ellos sirven para tomar decisiones colectivas acerca de los limites de funcionamiento de otros. [...] El límite real al poder de decisión de la mayoría no son los derechos constitucionalizados, sino lo que el órgano que ejerza el control jurisdiccional de constitucionalidad - $\mathrm{O}$ incluso meramente la mayoria de sus miembros- establezca que es el contenido de esos derechos: porque, por discutibles que puedan parecernos las decisiones que adoptan, su firmeza no está condicionada a su corrección material. Toda regla de decisión colectiva última, so pena de incurrir en regreso al infinito, tiene que ser estrictamente procedimental. 46

Lo que desemboca en una cuestión de "autoridad" que los sustantivistas dejan en manos de los jueces frente a otras instituciones, bajo la pretensión de que sus decisiones son más justas.

\section{Los arreglos institucionales en el neoconstitucionalismo}

De lo dicho anteriormente se desprende que la elección por un modelo de legitimidad sustancialista es determinan-

44 Garzón Valdés, "La alternativa del disenso. La propuesta de Javier Muguerza”, op. cit, p. 485.

45 Garzón Valdés, Ernesto, "El consenso democrático: fundamento y límites del papel de las minorías”, Isonomía, núm. 12, 2000, p. 9.

46 Bayón, "Derechos, democracia y Constitución", cit., p. 217.

PROBLEMA

Anuario de Filosofia y Teoria del Derecho, Núm. 8, enero-diciembre de 2014, pp. 227-306 
Esta revista forma parte del acervo de la Biblioteca Jurídica Virtual del Instituto de Investigaciones Jurídicas de la UNAM www.juridicas.unam.mx

http://biblio.juridicas.unam.mx

ANA MICAELA ALTERIO

te al momento de entender los arreglos institucionales propuestos por los neoconstitucionalistas. Así se suele calificar a estos arreglos como "elitistas" o de "constitucionalismo fuerte". ${ }^{47}$ Lo común a estas posturas es que identifican a las decisiones mayoritarias como potencialmente peligrosas y dan al derecho el lugar de la "corrección", ubicándolo como instancia externa a la política, que evita los excesos de mayorias coyunturales. Este modelo prioriza las decisiones pasadas sobre las presentes ${ }^{48}$ (rigidez constitucional) y establece un control judicial de las leyes "fuerte".

Lo que caracteriza este tipo de control judicial fuerte es, según Waldron, que los tribunales tienen la autoridad para negarse a aplicar una ley en un caso particular (a pesar de que la ley sea claramente aplicable al caso) o para modificar los efectos de esa ley de modo de volver su aplicación conforme con derechos individuales (en un modo en que la ley misma no prevé). Además, los tribunales en estos sistemas tienen la autoridad de establecer que una ley o disposición legislativa dada no sea aplicada, lo que la convierte de hecho en letra muerta. Una forma aún más fuerte de control judicial otorga poder a las cortes para suprimir directamente una parte de la legislación del cuerpo legislativo. ${ }^{49}$

47 Salazar Ugarte, Pedro, La democracia constituional, cit., pp. 91 y ss., 216. Al constitucionalismo de Ferrajoli se lo ha calificado incluso de "Constitucionalismo fortísimo". Véase De Lora, Pablo, "Luigi Ferrajoli y el constitucionalismo fortísimo", en Carbonell, Miguel y Salazar, Pedro (eds.), Garantismo, Estudios sobre el pensamiento jurídico de Luigi Ferrajoli, Madrid, Trotta-UNAM, Instituto de Investigaciones Jurídicas, 2005.

48 Para Luigi Ferrajoli, "las Constituciones tienen el fin de atar las manos a las generaciones presentes en cada momento a fin de impedir [...] que ellas amputen las manos de las generaciones futuras", Ferrajoli, Luigi, Dos modelos de constitucionalismo, cit., p. 84.

49 Waldron, "The Core of the Case Against Judicial Review", cit., p. 1354. El tipo de control judicial "más fuerte" es el propio de los países europeos con Tribunales Constitucionales concentrados, aunque según el autor los verdaderos efectos de la autoridad de la Corte norteamericana, no son muy diferentes. Ibidem, p. 1355. En igual sentido Prieto Sanchís, Justicia constitucional y derechos fundamentales, cit, p. 170. 
Esta revista forma parte del acervo de la Biblioteca Jurídica Virtual del Instituto de Investigaciones Jurídicas de la UNAM www.juridicas.unam.mx

http://biblio.juridicas.unam.mx

CONSTITUCIONALISMO CONTEMPORÁNEO A DEBATE

Como dije, la justificación para otorgar estos poderes a los jueces, se encuentra en la "salvaguarda" de los derechos fundamentales, que por la misma razón, se plasman en constituciones rígidas, reformulando así la noción de "soberanía popular", al punto de desvanecerla.50 Para Dworkin por ejemplo, a fin de alcanzar los principios de dignidad democráticos, es necesario consagrar ciertos derechos individuales en una constitución que deba ser interpretada por los jueces antes que por representantes electos, junto con la condición de que la constitución pueda reformarse sólo por super-mayorias. ${ }^{51}$

El mismo autor explica que la elección de un control de constitucionalidad en manos de los jueces se debe a que los jueces tienen una propensión a razonar con arreglo a principios, acorde a lo que él propone como "lectura moral de la constitución". ${ }^{2}$ Este modo de razonar de los jueces, no se debería a ninguna cualidad epistémica en ellos inherente, sino a una serie de condiciones estructurales: a) los jueces están obligados a confrontar todos los reclamos que se les plantean, b) tienen la obligación de justificar sus decisiones tomando como base el texto constitucional - que incluye principios - c) el cargo de juez goza de numerosas garantías institucionales que los vuelven menos vulnerables a múltiples presiones o coacciones. Todo ello haria más probable que los jueces razonen con arreglo a principios.

Pero como bien señala Waldron, esta asociación suele presentar una imagen un tanto irreal de cómo es la toma de decisiones judicial, desmereciendo las ventajas en términos de resultados que pueden hallarse del lado de las legislatu-

50 Véase Ferrajoli, Dos modelos de constitucionalismo, cit., p. 53, del mismo autor Democracia y garantismo, cit., p. 29, y Derechos y garantias. La ley del más débil, cit., pp. 125 y ss. donde trata el tema con más profundidad. En similar sentido Zagrebelsky, El derecho dúctil, cit., pp. 11 y 12 .

51 Dworkin, Ronald, La democracia posible: principios para un nuevo debate politico, trad. de Ernest Weikert García, Barcelona, Paidós Ibérica, 2008, p. 183.

52 Dworkin, Ronald, Freedom's Law. The Moral Reading of the American Constitution, Oxford University Press, 1996, p. 2. 
Esta revista forma parte del acervo de la Biblioteca Jurídica Virtual del Instituto de Investigaciones Jurídicas de la UNAM www.juridicas.unam.mx

http://biblio.juridicas.unam.mx

ANA MICAELA ALTERIO

ras. ${ }^{53}$ Ahondaré en estas críticas infra. Lo cierto es que estos arreglos institucionales hacen que la teoría sea calificada de "elitista" o "progresista", para usar la terminología de Balkin, y que se enfrente directamente con las posiciones "populistas". ${ }^{44}$ La principal diferencia que encuentra Balkin entre estas formas de pensamiento tiene que ver con la actitud que toman frente a las creencias, actitudes y acciones de la masa de "ciudadanos comunes". 55

Así el "progresismo" históricamente habria estado preocupado por el buen gobierno y las politicas públicas ilustradas para el bien común. Considera que personas educadas y civilizadas pueden, a través del uso de la razón, determinar qué es lo mejor para la sociedad toda. La persuasión, discusión y el diálogo racional harian viable que individuos con diferentes visiones puedan acordar lo que requiere el interés público. Por ello se propicia que el gobierno y la participación pública se estructuren de modo de producir deliberaciones racionales y consenso acerca de las más importantes politicas públicas. En este proceso, la cultura y voluntad populares tendrian un papel que jugar, pero sólo después de una educación suficiente y de que sus elementos más pasionales hayan sido difuminados. ${ }^{56}$ 1379

53 Waldron, "The Core of the Case Against Judicial Review", cit., p. 379.

54 Balkin, Jack M., "Populism and Progressivism as Constitutional Categories", Faculty Scholarship Series, Paper 268, 1995, pp. 1935-1990. Si bien el autor resalta que estas formas de pensamiento pueden darse tanto dentro del discurso liberal de izquierda como dentro del discurso conservador, centra su trabajo en el primero de ellos y lo mismo pretendo yo en este artículo. Ibidem, p. 1944.

55 Ibidem, p. 1945. En igual sentido Parker, Richard, "Here, The people Rule: A Constitutional Populist Manifiesto", Valparaiso University Law Review, vol. 27, núm. 3, 1993, p. 532, distingue dos tipos de "sensibilidades" y las llama "antipopulista" y "populista", p. 553.

56 Balkin, "Populism and Progressivism as Constitutional Categories", cit., p. 1947.

PROBLEMA

Anuario de Filosofia y Teoría del Derecho, Núm. 8, enero-diciembre de 2014, pp. 227-306 
Esta revista forma parte del acervo de la Biblioteca Jurídica Virtual del Instituto de Investigaciones Jurídicas de la UNAM www.juridicas.unam.mx

http://biblio.juridicas.unam.mx

CONSTITUCIONALISMO CONTEMPORÁNEO A DEBATE

Es que el "progresismo" 57 suele identificar la participación politica ordinaria, común o popular como problemática, derivada de estados mentales o temperamentos defectuosos: emocionales, ignorantes, simples, irresponsables, arbitrarios, impulsivos, vulnerables a cualquier influencia o manipulación, etcétera ${ }^{58}$ y que tienen sus efectos en la ley ordinaria. Frente a ello y como vimos, apuesta por una política de "mejor calidad" (alta política) que se refleja en la "inflación" del derecho constitucional. ${ }^{59} \mathrm{El}$ derecho constitucional, según este discurso, tiene la misión de "corregir los fallos presuntamente endémicos de la regla de la mayoría" y de salvaguardar a los individuos, las minorías o incluso algún órgano gubernamental, amenazados por la fuerza de la política ordinaria. ${ }^{60}$

Esta misión la lleva a cabo a través de los jueces, quienes estarian más calificados al momento de la toma de decisiones, en tanto se hallan aislados de las presiones de la política ordinaria y pueden "trascenderla", se presume que son razonables y que no están animados por intereses egoístas. Incluso para reforzar ese aislamiento, afirma Parker, el derecho constitucional ha generado metodologias abstractas de razonamiento sobre sus temas (standards) que, por un lado, han erosionado la capacidad de la gente común de tomar parte de esos argumentos y, por otro lado, han amplificado la voz de la academia. ${ }^{61}$ En este sentido, ejemplos cla-

57 O "anti-populismo" como discurso convencional en el derecho constitucional. Parker, op. cit., p. 558.

58 Ibidem, p. 553, en oposición a conductas más "refinadas", racionales, informadas, complejas, basadas en principios, deliberadas, independientes, críticas, etcétera.

59 Ibidem, p. 558. O lo que, según la definición de Guastini sería la "constitucionalización del derecho", véase nota 17.

60 Ibidem, p. 560. De hecho, según el autor, el anti-populismo encuentra a la política ordinaria o de la mayoría como peligrosa, en tanto si se le da libertad para gobernar resultará prejuiciosa, intolerante y tiránica. Ibidem, p. 569.

61 El autor señala que desde la década de los ochenta se ha generado una especie de "teoría constitucional" que se dedica a sistematizar esta 
Esta revista forma parte del acervo de la Biblioteca Jurídica Virtual del Instituto de Investigaciones Jurídicas de la UNAM www.juridicas.unam.mx

http://biblio.juridicas.unam.mx

ANA MICAELA ALTERIO

ros serían los relativos a las teorías neoconstitucionales de la ponderación, de la argumentación ${ }^{62}$ o más aún, el método "axiomático" que utiliza Ferrajoli para su teoría y que se traduce en un volumen de más de 800 páginas de fórmulas lógicas ${ }^{63}$ que pretenden reflejar un "sistema de conceptos y enunciados organizado según una estructura formal rigurosa y exactamente preestablecida"; ${ }^{4}$ prácticamente inaccesible para los no expertos en derecho.

\section{3. ¿Qué teoría de la democracia?}

Evidentemente sería osado aunar a todos los neoconstitucionalistas como sostenedores de una teoría de la democracia. Pero nuevamente, podemos encontrar en las que propician ciertos rasgos comunes que intentaré reflejar aquí brevemente.

De forma coherente a los modelos de legitimidad, la mayor parte de los neoconstitucionalistas sostienen lo que se puede llamar una democracia "sustancial" que da un valor técnico a la regla de las mayorías. ${ }^{65}$ Así se sostiene que "de-

inflación de metodologías de razonamiento para que puedan informar los argumentos constitucionales. Ibidem, p. 562.

62 Véase Alexy, Robert, Teoria de los derechos fundamentales, trad. de Ernesto Garzón Valdés, Madrid, Centro de Estudios Constitucionales, 1993, pp. 96 y 97,161; también del autor El concepto y la validez del derecho, 2a. ed., trad. de Jorge Malem Seña, Barcelona, Gedisa, 2004, y Teoría de la argumentación jurídica: la teoría del discurso racional como teoría de la fundamentación jurídica, 2a. ed., trad. de Manuel Atienza y Isabel Espejo, Madrid, Centro de Estudios Políticos y Constitucionales, 2008; seguido a su vez por Atienza, Manuel, El derecho como argumentación, Barcelona, Ariel, 2006.

63 Véase Ferrajoli, Principia Iuris, cit., t. III: La sintaxis del derecho.

64 Ferrajoli, Principia Iuris, cit., t. I, p. 48.

65 Tradicionalmente se han propuesto dos clases de argumentos para justificar la regla de las mayorías: los argumentos técnicos, que la justifican porque constituye un instrumento óptimo para decidir en una colectividad cualquiera y los argumentos axiológicos, que la justifican por los valores que promueve. Bobbio, Norberto, "La regla de mayoria: límites y 
Esta revista forma parte del acervo de la Biblioteca Jurídica Virtual del Instituto de Investigaciones Jurídicas de la UNAM www.juridicas.unam.mx

http://biblio.juridicas.unam.mx

CONSTITUCIONALISMO CONTEMPORÁNEO A DEBATE

bemos abandonar la idea popular de que la regla de la mayoría es un procedimiento de toma de decisiones especialmente justo, incluso en política. El mero peso de los números por sí solo no aporta ningún valor a una decisión politica". 66

En esa lógica, cuando se restringe el poder de la mayoría para impedir que sus decisiones menoscaben los derechos fundamentales, el ideal democrático no sufriría daño alguno: al contrario, lo que se estaría haciendo es proteger a la democracia de lo que puede ser una seria amenaza para ella. En este sentido el Estado Constitucional resultaría ser precisamente "la juridificación de la democracia". ${ }^{67}$

Según la definición de Ferrajoli, por democracia "sustancial" se entiende el conjunto de límites y vínculos impuestos por los derechos y por los principios constitucionales tanto a la validez de las leyes como a la democracia política. ${ }^{68}$ En una línea similar, Dworkin propicia una democracia "asociativa", ${ }^{69}$ frente a la noción "mayoritaria" de la democracia: "la concepción asociativa no considera la democracia independiente del resto de la moralidad política; según esta concepción, necesitamos una teoría de la igualdad asociativa para decidir qué es o qué no es una decisión democrática, y necesitamos recurrir a las ideas de justicia, igualdad y libertad para construir tal teoría. Por tanto [...] la democra-

aporias", en Bovero, Michelangelo (ed.), Teoría general de la politica, Madrid, Trotta, 2003, pp. 466 y ss. En igual sentido Salazar Ugarte, Pedro, La democracia constitucional, cit., p. 133.

66 Dworkin, La democracia posible, cit., p. 181.

67 Bayón, Juan Carlos, "Democracia y Derechos: problemas de fundamentación del constitucionalismo", en Carbonell, Miguel y García Jaramillo, Leonardo (eds.), El canon neoconstitucional, cit., p. 293.

68 Ferrajoli, Democracia y garantismo, cit., p. 88.

69 En otros trabajos Dworkin clasifica como democracia "constitucional" aquella que se contrapone a la concepción mayoritarista. Véase Dworkin, Ronald, "La lectura moral y la premisa mayoritaria", en Hongju Koh, Harold y Slye, Ronald (comps.), Democracia deliberativa y derechos humanos, Barcelona, Gedisa, 2004, p. 117. 
Esta revista forma parte del acervo de la Biblioteca Jurídica Virtual del Instituto de Investigaciones Jurídicas de la UNAM www.juridicas.unam.mx

http://biblio.juridicas.unam.mx

ANA MICAELA ALTERIO

cia es un ideal sustantivo no meramente procedimental", 70 cuya estructura, composición y prácticas trata a todos los miembros de la comunidad como individuos, con igual consideración y respeto. ${ }^{71}$

Otros neoconstitucionalistas optan por una noción "deliberativa" de la democracia ${ }^{72}$ que no necesariamente es sustancialista pero que, en general, se acompaña con fuertes "precondiciones"73 y finalmente, un apoyo ambiguo al control judicial de constitucionalidad. Un ejemplo claro de este tipo de posturas lo encontramos en Nino, ${ }^{74}$ para quien la democracia tiene un valor epistémico en tanto constituye un método de discusión y de decisión colectiva que, bajo ciertas condiciones, permite identificar "decisiones moralmente correctas". ${ }^{75}$ Estas condiciones o derechos a priori son para Nino "condiciones de validez del proceso democrático y su valor no se encuentra determinado por el proceso

70 Dworkin, La democracia posible, cit., p. 170.

71 Dworkin, "La lectura moral y la premisa mayoritaria", cit., p. 117.

72 Mucho se ha escrito sobre la democracia deliberativa, en este sentido véase Elster, Jon (comp.), La democracia deliberativa, Barcelona, Gedisa, 2001; Habermas, Jürgen, Facticidad y validez. Sobre el derecho y el Estado democrático de derecho en términos de teoría del discurso, 5a. ed., trad. de Manuel Jiménez Redondo, Madrid, Trotta, 2008; Gutmann, Amy y Thompson, Dennis, Why Deliberative Democracy?, Princeton, Princeton University Press, 2004; Rainer, Forst, "The Rule of Reasons. Three Models of Deliberative Democracy", Ratio Juris, vol. 14, núm. 4, diciembre de c2001, pp. 345-378. Siguiendo a este último autor, podríamos calificar de "liberal" al tipo de democracia deliberativa que adoptan los neoconstitucionalistas.

73 Como lo enfatiza Kramer, "Popular Constitutionalism, circa 2004", cit., p. 1005, el mismo autor también en "Undercover Anti-Populism", Fordham Law Review 73, 2005, pp. 1351 y ss.

74 Cuya concepción de la democracia deliberativa más bien podría enrolarse dentro del procedimentalismo. Una confrontación entre la teoría de Nino y el Constitucionalismo popular en Gargarella, Roberto, "Una disputa imaginaria sobre el control judicial de las leyes. El "Constitucionalismo popular" frente a la teoría de Nino", en Carbonell y García (eds.), El canon neoconstitucional, cit., pp. 403-426.

75 Nino, Carlos Santiago, La constitución de la democracia deliberativa, trad. de Roberto Saba, Barcelona, Gedisa, 2003, p. 180. 
Esta revista forma parte del acervo de la Biblioteca Jurídica Virtual del Instituto de Investigaciones Jurídicas de la UNAM www.juridicas.unam.mx

http://biblio.juridicas.unam.mx

CONSTITUCIONALISMO CONTEMPORÁNEO A DEBATE

sino que está presupuesto por éste”, deben ser respetados como prerrequisitos de su validez y es misión de los jueces garantizar ese respeto. ${ }^{76} \mathrm{Si}$ bien es verdad que el control de constitucionalidad se presenta aquí como "excepcional", ${ }^{77}$ lo cierto es que se termina justificando su existencia por sobre la voluntad mayoritaria.

Podría decirse que los ideales de democracia que defienden los neoconstitucionalistas deliberativistas (y que marcan el contrapunto con los populistas deliberativistas) se basan en la "persuasión, la discusión, el diálogo racional", favoreciendo la "soberanía de la razón" frente a la "soberanía popular"78 y poniendo el acento en el consenso como valor central. ${ }^{79} \mathrm{En}$ este esquema, los gobiernos tendrian el deber de moldear las preferencias privadas para promover los ideales de la deliberación democrática. ${ }^{80}$

\section{La relación entre derecho y politica}

Finalmente, otra de las características propias del neoconstitucionalismo es que centra su labor en el constitucionalismo "jurídico". Así, si bien acepta unos orígenes políti-

76 Ibidem, p. 275.

77 Nino habla de tres casos excepcionales en los que correspondería dicho control encaminado a proteger las condiciones que harian epistémicamente confiable el ideal democrático: 1) el control del procedimiento; 2) la defensa de la autonomía personal y 3) la protección de la constitución como resultado de la acción colectiva. Ibidem, pp. 128, 130.

78 Gargarella, "Una disputa imaginaria sobre el control judicial de las leyes...", cit., p. 416.

79 Según la crítica de Waldron, Jeremy, Derecho y desacuerdos, trad. de Martí, José Luis y Quiroga, Águeda, Madrid, Marcial Pons, 2005, p. 111 , donde aclara: "aceptar el consenso como la lógica interna de la deliberación no es lo mismo que estipularlo como el resultado político correcto".

80 Balkin, "Populism and Progressivism as Constitutional Categories", cit., pp. 1967, 1983. 
Esta revista forma parte del acervo de la Biblioteca Jurídica Virtual del Instituto de Investigaciones Jurídicas de la UNAM www.juridicas.unam.mx

http://biblio.juridicas.unam.mx

ANA MICAELA ALTERIO

cos del derecho, ${ }^{81}$ luego lo jurídico pareciera desprenderse o "autonomizarse" de lo político o peor aún, cambiar su orden lógico quedando la política atada a lo jurídico que le cierra la puerta a cualquier influencia. En este sentido podríamos decir que se asume que, lo que en un momento anterior al paradigma constitucional pudo haber sido materia de deliberación política, una vez positivado en constituciones, cambia su naturaleza controvertida para volverse una "verdad" absoluta y expulsar del discurso cualquier otro principio que por no coincidir (o estar en contra) con el positivizado, se torna ilegitimo. ${ }^{82}$ Aquí, es necesario hacer algunas distinciones y para ello me valdré de los puntos de vista interno y externo de la teoría del derecho.

Desde el punto de vista interno, asumiendo incluso el diseño institucional dado por una constitución rígida y la configuración de un órgano jurisdiccional encargado de custodiarla mediante decisiones no revisables por el legislador; es muy difícil negar la necesidad de discusión/decisión política en cuanto a los alcances de esa constitución. Es decir, son pocos los autores que niegan el conflicto de derechos (aunque uno bien paradigmático es Ferrajoli) ${ }^{83}$ tanto

81 Por ejemplo Ferrajoli desprende de la ideología constitucionalista (o del constitucionalismo político) al constitucionalismo jurídico, que vendría a ser la institucionalización del primero y además, un perfeccionamiento del mismo al dotarlo de garantías positivas mediante constituciones rígidas. Ferrajoli, Principia Iuris, cit., t. I, p. 469.

82 Vale aclarar que aquí la legitimidad no hace alusión a la legitimidad política o externa - es decir, a los parámetros no jurídicos, ético-políticos- sino que se redefine como término teórico-jurídico para designar la regularidad de las situaciones y de las normas. Véase ibidem, pp. 551 y 552 , nota 38 .

83 Quien considera a los derechos como "reglas", es decir, consignas claras que únicamente pueden generar discusión en cuanto a sus medios de concreción pero no en cuanto a sus contenidos, ni tampoco entrar en conflicto entre sí. De hecho, Ferrajoli asimila el derecho constitucional al derecho penal, auspiciando la mayor taxatividad del primero a fin de excluir cualquier consideración política. Ferrajoli, "Costituzionalismo principialista e costituzionalismo garantista”, cit., pp. 2798-2799, 2807, 
Esta revista forma parte del acervo de la Biblioteca Jurídica Virtual del Instituto de Investigaciones Jurídicas de la UNAM www.juridicas.unam.mx

http://biblio.juridicas.unam.mx

CONSTITUCIONALISMO CONTEMPORÁNEO A DEBATE

en cuanto a su significado, como de derechos entre sí. Así los neoconstitucionalistas, a través de sus teorías de los derechos fundamentales como principios (con un lenguaje fuertemente valorativo y que no predetermina las relaciones de prevalencia) y de la ponderación, terminan dejando entrar a "la política" al interior del modelo. Es en este sentido ejemplificativa la posición de Ruiz Manero “... una constitución así diseñada mantiene abierto el proceso deliberativo [...] y de esta forma evita en gran medida la 'tiranía de los muertos sobre los vivos' que se ha reprochado frecuentemente al constitucionalismo rígido". 84

Lo que ocurre es que, con estas restricciones institucionales, esas decisiones políticas están muy limitadas para el legislador y más bien se dejan en manos de los jueces, quienes tienen la última palabra en materia de interpretación constitucional. ${ }^{85}$ Lo que, dada la escasa posibilidad de control a la que están sometidos ${ }^{86}$ y la discrecionalidad que

2812-2816. Un análisis de este punto en Alterio, "El ius-constitucionalismo de Luigi Ferrajoli desde una mirada política”, cit.

84 Ruiz Manero, Dos modelos de constitucionalismo, cit., p. 80. Una idea similar en Zagrebelsky, "Jueces constitucionales" cit., pp.97-99. He de decir que este "inevitable" ingreso de la politica en el derecho no es reconocido por autores como Dworkin, quien entiende que hasta en los "casos dificiles" hay una respuesta jurídica correcta. Véase Dworkin, Ronald, "¿Realmente no hay respuesta correcta en los casos dificiles? en Casanovas, Pompeu y Moreso, Juan (eds.) El ámbito de lo jurídico. Lecturas de pensamiento jurídico contemporáneo, Barcelona, Crítica, 1994. En una línea similar, aunque con una tesis más moderada, encontramos por ejemplo a Alexy, Robert "Sistema jurídico, principios jurídicos y razón práctica”, Doxa, núm. 5, 1988.

85 Véase Dworkin, La democracia posible, cit., p. 195.

86 La que se acrecienta si se niega — como hacen Dworkin o Alexy- la discrecionalidad en su actuación, generando una irresponsabilidad que proviene de la sustracción del juez al control propio del principio de legalidad en sentido material. Véase García Figueroa, Principios y positivismo jurídico, cit., p. 317 . En este sentido se podría decir que la "política" entra disfrazada de tecnicismos. 
Esta revista forma parte del acervo de la Biblioteca Jurídica Virtual del Instituto de Investigaciones Jurídicas de la UNAM www.juridicas.unam.mx

http://biblio.juridicas.unam.mx

ANA MICAELA ALTERIO

su labor lleva ínsita, hace que su legitimidad esté en permanente cuestión. ${ }^{87}$

Ahora bien, desde el punto de vista externo, el encorsetamiento de la política es aún más preocupante. El identificar los principios constitucionales con principios morales "correctos" 88 y la consecuencia de positivarlos rígidamente mediante cotos vedados, hace que el discurso ético-político crítico, quede relegado. Ya vimos cómo Ferrajoli nos hablaba del paso de estos principios "de fuentes de legitimación politica o externa en fuentes de legitimación (y si son violados, de deslegitimación) también jurídica o interna", ${ }^{89}$ o cómo Garzón Valdés insiste en que dentro del "coto vedado" no rige el "principio de no dictadura" porque la no aceptación es una clara señal de irracionalidad o de ignorancia, lo que justifica en última instancia, el paternalismo de una generación hacia otra. ${ }^{90}$

Esto que sólo casa con una teoría fuertemente iusnaturalista, no se condice con una noción de constitución como derecho positivo, derecho "puesto", contingente, históricamente determinado, expresión del poder y también de luchas sociales. Si en un momento dado -y en el mejor de los casos - unas mayorías crearon una constitución que hoy merece la pena ser respetada, ¿por qué negar a futuro la posibilidad de que se considere ese derecho (o parte de él) "injusto" y se pretenda modificarlo?91

87 Zagrebelsky, “Jueces constitucionales", cit., p.96.

88 En este punto véase Alexy, El concepto y la validez del derecho, cit., pp. 82 y 83 .

89 Véase supra nota 24. Es que para Ferrajoli, en una democracia constitucional, legitimación sustancial externa e interna son "las dos caras de la misma moneda"; es decir, se identifican. Ferrajoli, Principia Iuris, cit., t: I, p. 852; también t: II: Teoría de la democracia, pp. 37, 47, 90.

90 Garzón, "El consenso democrático: fundamento y límites del papel de las minorias", cit., p. 17.

91 Como nos enseña Dussel, la situación crítica se da cuando un sector de la ciudadanía es excluida - no intencionalmente- del ejercicio de nuevos derechos que el "sistema del derecho" no ha incluido todavía. Estos (as) ciudadanos (as) con conciencia de ser sujetos de nuevos dere- 
Esta revista forma parte del acervo de la Biblioteca Jurídica Virtual del Instituto de Investigaciones Jurídicas de la UNAM www.juridicas.unam.mx

http://biblio.juridicas.unam.mx

CONSTITUCIONALISMO CONTEMPORÁNEO A DEBATE

Si no se encuentran en el sistema jurídico y/o en la teoría del derecho canales para captar esas exigencias legítimas (desde un punto de vista ético-político, aunque no legal) de los "pueblos", de los movimientos sociales; la posibilidad de un cambio en materia de derechos sólo puede ser viable a través de una revolución. A esto lleva la teoría neoconstitucional, al propiciar constituciones rígidas $\mathrm{y}$ con contenido indecidible, al punto de que - para algunos autores- ni siquiera a través de una reforma constitucional se podrian modificar. ${ }^{92}$ De hecho, por seguir con Ferrajoli, de darse una reforma, también ésta debería ser sometida a control de constitucionalidad. ${ }^{93} \mathrm{Ni}$ hablar de quienes directamente conectan los derechos fundamentales con la moral (como la mayor parte de los neoconstitucionalistas hace) que asfixian la posibilidad de innovación jurídica y excluyen a los potenciales disidentes de ingresar o al menos de participar en el juego institucional.

\section{El CONSTITUCIONALISMO POPULAR}

A diferencia del neoconstitucionalismo, el constitucionalismo popular, en línea con la orientación pragmática de la

chos se experimentan a sí mismos como víctimas, sufriendo los efectos negativos del cuerpo del derecho. Los movimientos de los "sin derecho todavia" (respecto del derecho vigente) comienzan una lucha por la inclusión de los "nuevos" derechos en la "lista" histórica de los derechos ya aceptados, institucionalizados, vigentes. Se establece así una dialéctica entre "derecho vigente a priori versus nuevo derecho a posteriori". Los y las "sin derecho todavía", cuando luchan por el reconocimiento de un nuevo derecho son el momento creador histórico del cuerpo del derecho humano". Dussel, Enrique, "Hacia una filosofia política crítica", Bilbao, Desclée de Brouwer, 2001, pp. 150 y ss.

92 Ferrajoli, Principia Iuris, cit.,t. II, p. 86.

93 Que anulará las reformas que contradigan las disposiciones formales y sustanciales de la constitución reformada. Ibidem, t. I, pp. 811, 843. Con sus palabras: “...una vez estipulados constitucionalmente, los derechos fundamentales no se hallan en el ámbito de disponibilidad de la mayoría y deberian quedar sustraídos también al poder de revisión...". Ibidem, p. 875. 
Esta revista forma parte del acervo de la Biblioteca Jurídica Virtual del Instituto de Investigaciones Jurídicas de la UNAM www.juridicas.unam.mx

http://biblio.juridicas.unam.mx

ANA MICAELA ALTERIO

teoría del derecho norteamericana, se ha desarrollado mayormente como un ejercicio a-teorético basado en estudios históricos y en alusiones a sus posibilidades. ${ }^{94}$ Lo que intenta es recuperar el debate en torno al papel del "pueblo" en la discusión y decisión de los asuntos constitucionales; y si bien - como se dijo- no lo hace de modo uniforme, todos los que se han vinculado con esta forma de pensar el constitucionalismo, consideran que éste debe pasar a ocupar un lugar central o más central en la vida constitucional de sus propias comunidades. ${ }^{95}$

A pesar de estas diferencias y a los fines de hacer posible el cotejo propuesto, intentaré resumir algunos presupuestos de fondo (no exclusivos tampoco de esta escuela) que la enfrentan claramente al neoconstitucionalismo y que, por eso mismo, surgen como "alternativa" para repensar el constitucionalismo en América Latina. ${ }^{96}$ Así, se puede realizar una confrontación -normativa- con las notas que se señalaron como parte del fenómeno de "constitucionalización del ordenamiento jurídico" 97 propio del neoconstitucionalismo. En ese sentido, se podría decir que el constitucionalismo popular propicia: 1) Flexibilizar la constitución y excederla; 2) Desafiar la supremacía judicial $-\mathrm{y}$ en ciertos casos incluso impugnar cualquier forma de control judicial

94 Tushnet, Mark, "Prefacio", Constitucionalismo popular en Latinoamérica, cit., p. IX.

95 Gargarella, Roberto, "Prólogo", Constitucionalismo popular en Latinoamérica, cit., p. XIII.

96 Podría decirse de hecho que el constitucionalismo popular surge como una reacción al elitismo que distingue a la reflexión jurídica contemporánea, aunque no entre en diálogo directamente con el neoconstitucionalismo como lo he caracterizado, por circunscribirse a la experiencia norteamericana. Véase Gargarella, Roberto, "El nacimiento del constitucionalismo popular. Sobre The people Themselves, de Larry Kramer", Revista de libros de la Fundación Caja Madrid, núm. 112, abril de 2006, disponible en: http://www.revistadelibros.com/articulo_imprimible_pdf.php? art $=2799 \&$ t $=$ articulos.

97 Véase nota 17. 
Esta revista forma parte del acervo de la Biblioteca Jurídica Virtual del Instituto de Investigaciones Jurídicas de la UNAM www.juridicas.unam.mx

http://biblio.juridicas.unam.mx

CONSTITUCIONALISMO CONTEMPORÁNEO A DEBATE

de constitucionalidad-;98 3) La interpretación extrajudicial de la constitución;99 4) La democratización y participación en las instituciones politicas y económicas;100 5) La recuperación de la relación entre derecho y politica.

En lo que sigue, reagruparé estas notas en categorias comparables a las que utilicé para analizar el neoconstitucionalismo.

\section{El modelo procedimentalista de legitimidad}

Al igual que en el caso del aludido sustancialismo "débil", el procedimentalismo al que adhieren los populares también es "mixto" y por tanto no está privado de valores sustanciales, sólo que al momento de la toma de decisión se decantan por la prevalencia de la dimensión procedimental. Podriamos decir con Zurn que el modelo procedimentalista de legitimidad encuentra justificados los resultados de un proceso de toma de decisiones simplemente porque se cum-

98 Para esto se basan en estudios empíricos sobre los efectos que ha tenido el control judicial de las leyes, desmistificando las visiones dominantes y mostrando la limitada capacidad de los tribunales para frenar o revertir las políticas adoptadas por los poderes ejecutivo y legislativo, o para imponer directamente su propia agenda. Véase Gargarella, "El nacimiento del constitucionalismo popular...", cit.. Asimismo algunos intentan demostrar cómo el sostener un compromiso fuerte con la idea de derechos no implica necesariamente apoyar un sistema institucional con control de constitucionalidad de las leyes y para ello se valen de la experiencia de países donde no existe tal control (fuerte) y se respetan igualmente los derechos fundamentales. Véase Waldron, Jeremy, "A Right-Based Critique of Constitutional Rights", Oxford Journal of Legal Studies, vol. 13, núm. 1, Oxford University Press, 1993, p. 19.

99 Según Kramer, éste es el principio básico del constitucionalismo popular, es decir, la idea de que los ciudadanos comunes son los intérpretes principales de la constitución, que sus visiones acerca del significado de la constitución, expresadas colectivamente, reflejan la máxima autoridad cuando se trata de resolver desacuerdos acerca de lo que la constitución permite, prohíbe o requiere. Kramer, Larry, "Undercover Anti-Populism”, cit., p. 1344.

100 Gargarella, "El nacimiento del constitucionalismo popular...", cit. 
Esta revista forma parte del acervo de la Biblioteca Jurídica Virtual del Instituto de Investigaciones Jurídicas de la UNAM www.juridicas.unam.mx

http://biblio.juridicas.unam.mx

ANA MICAELA ALTERIO

plieron las específicas condiciones del procedimiento. ${ }^{101}$ Respecto del contenido de la decisión, se sostiene que los desacuerdos sustantivos son tan amplios, tan profundos y persistentes, que no se puede juzgar la corrección de la misma y sólo queda confiar en los procedimientos para fundar una teoría de la legitimidad. ${ }^{102}$

En consecuencia se propone un derecho constitucional también orientado a los procedimientos, cuya misión sea mejorar el proceso democrático y, animado por las elecciones controvertidas de valores, afirme que las controversias más importantes deben ser decididas a través de la politica democrática. ${ }^{103}$ Es que, como afirma Waldron:

en la medida en la que estos tan aclamados valores objetivos no logren aparecer ante nosotros [...] en formas que no dejen margen para desacuerdos adicionales sobre su carácter, todo lo que tenemos en la tierra son opiniones o creencias sobre valores objetivos... ${ }^{104}$

Por lo que una teoría de derechos necesariamente debe complementarse con una teoría de la autoridad, cuya función será determinar qué decisiones se tomarán cuando los miembros de una comunidad están en desacuerdo acerca de qué decisión es la correcta. ${ }^{105}$

Ahora bien, esta primera caracterización podría sonar muy "radical" si no fuera porque para elegir ese procedimiento de toma de decisiones, se apela a valores sustantivos: así el mismo autor sostiene que en las circunstancias

\footnotetext{
101 Zurn, op. cit., p. 477.

102 Linares, op. cit., p 31.

103 Parker, op. cit., p. 579.

104 Waldron, Jeremy, "Deliberación, desacuerdo y votación”, en Hongju Koh, Harold y Slye, Ronald (comp.) Democracia deliberativa y derechos humanos, cit., p. 262.

105 Waldron, "A Right-Based Critique of Constitutional Rights", cit., pp. 32 y ss., del mismo autor Derecho y desacuerdos, cit., p. 253.
} 
Esta revista forma parte del acervo de la Biblioteca Jurídica Virtual del Instituto de Investigaciones Jurídicas de la UNAM www.juridicas.unam.mx

http://biblio.juridicas.unam.mx

CONSTITUCIONALISMO CONTEMPORÁNEO A DEBATE

de la política ${ }^{106}$ el derecho de participación en pie de igualdad tiene una primacía absoluta porque honra el valor de la igual dignidad y autonomía personal, un valor subyacente a la misma noción de derechos. ${ }^{107}$ Así se "cierra el círculo", dado que el derecho a participar en términos equitativos en las decisiones que el procedimiento pueda contemplar, es la clave para determinar la mayor o menor legitimidad de un procedimiento para la toma de decisiones colectivas. ${ }^{108}$

Quienes comparten este modelo de legitimidad, reclaman a los sustancialistas el optar por un esquema de justificación instrumental, ${ }^{109}$ es decir, valioso en tanto susceptible de generar mayor probabilidad de respuestas correctas, desconociendo una dimensión importante a la hora de evaluar el diseño de las instituciones. Esta dimensión —que rescatan los procedimentalistas - tiene que ver justamente con los criterios para evaluar el procedimiento mismo y que son independientes del valor de los resultados que es probable

106 Que vienen dadas por "la sensación de necesidad de una política compartida o una decisión o curso de acción sobre una cuestión determinada entre los miembros de un grupo determinado, incluso frente al desacuerdo sobre cómo debería ser esa política, esa decisión o ese curso de acción". Ibidem, p. 123.

107 Linares, op. cit., p. 32. Véase Waldron, Derecho y desacuerdos, cit., pp. 338 y ss. donde el autor afirma: "Los teóricos discrepan sobre si la democracia es algo más que un ideal procedimental, pero ciertamente entraña al menos la idea de un procedimiento político constituido en parte por determinados derechos". A estos derechos los llama "constitutivos del proceso democrático y el caso más claro es el aludido derecho de participación. Pero también se refiere a los derechos que, aunque no sean formalmente constitutivos de la democracia, representan en todo caso condiciones necesarias para su legitimidad y pone como ejemplo la libertad de expresión, la libertad de asociación, etcétera.

108 Moreno Rodríguez Alcalá, Diego, Control judicial de la ley y derechos fundamentales. Una perspectiva critica, Madrid, Centro de Estudios Politicos y Constitucionales, 2011, p. 80.

109 Que se basa en el presupuesto rawlsiano según el cual el único esquema adecuado para los procesos de decisión empleados en el ámbito público será uno de justicia procesal imperfecta. Ibidem, pp. 76 y 77. 
Esta revista forma parte del acervo de la Biblioteca Jurídica Virtual del Instituto de Investigaciones Jurídicas de la UNAM www.juridicas.unam.mx

http://biblio.juridicas.unam.mx

ANA MICAELA ALTERIO

que produzca. ${ }^{110}$ Lo que determinará entonces la justificación de un procedimiento para la toma de decisiones será un balance entre su valor intrinseco y su valor instrumental. ${ }^{111}$

Podriamos pensar que finalmente ambas formas de legitimidad "débiles" tienden a disputarse ese dificil equilibrio que suele presentarse como paradoja entre la justicia de los procedimientos democráticos y la justicia de los resultados obtenidos mediante ese procedimiento. ${ }^{112}$ Lo cierto es que la gran diferencia se percibe en los arreglos institucionales que cada una desprende de ellos. Ya vimos que el neoconstitucionalismo confia en que los jueces velarán por esos valores sustantivos que el procedimiento no debería vulnerar. Veamos ahora qué dicen los populares. ${ }^{113}$

110 Bayón, "Democracia y derechos...", cit., p. 315. De forma contundente Waldron, "The Core of the Case Against Judicial Review", cit., p. 1371 , nota 65 nos dice: “...a normative political theory needs to include more than just a basis for justifying certain decisions on their merits [...] It also has to address the normative issue of the legitimacy of the decision-procedures that are used to make political decisions in the face of disagreement".

111 Bayón, “Democracia y derechos...”, cit., p. 315.

112 Véase sobre el punto Martí, José Luis, La república deliberativa. Una teoria de la democracia, Madrid, Marcial Pons, 2006, donde el autor distingue y analiza dos paradojas: la que aquí se menciona y la llamada "paradoja de las precondiciones de la deliberación democracia", que si bien tiene un parentesco con la anterior, es más restringida a ciertos modelos de democracia que muestran un fuerte compromiso con los derechos. Sobre esta última, del mismo autor: "Un callejón sin salida. La paradoja de las precondiciones (de la democracia deliberativa) en Carlos S. Nino", en Alegre, Marcelo et al. (coords.), Homenaje a Carlos S. Nino, Buenos Aires, La Ley, 2008. Una crítica a la visión de Martí en Ruiz Miguel, Alfonso, "Lo no deliberable de la democracia deliberativa", Diritto \& Questioni Pubbliche, núm. 9, 2009.

113 No es el objeto de este artículo desarrollar el procedimentalismo en sí, ni todos los arreglos institucionales que se pueden desprender de sostenerlo. Baste señalar que normalmente se asocia a esta corriente el preferir a las asambleas legislativas — frente a cualquier órgano del Estadoal momento de tomar decisiones, cosa que en el constitucionalismo popular no es tan clara, desde que en algunos casos esa autoridad se difumina 
Esta revista forma parte del acervo de la Biblioteca Jurídica Virtual del Instituto de Investigaciones Jurídicas de la UNAM www.juridicas.unam.mx

http://biblio.juridicas.unam.mx

CONSTITUCIONALISMO CONTEMPORÁNEO A DEBATE

\section{Los arreglos institucionales en el constitucionalismo popular}

En franca oposición a los modelos que calificamos como "elitistas" o de "constitucionalismo fuerte", el constitucionalismo popular propicia diseños institucionales de constitucionalismo "débil"114 o "populistas". A grandes rasgos, se puede decir que esta corriente percibe al derecho como la instancia que traduce las decisiones politicas mayoritarias, por lo que es dinámico y cambiante; se propicia la interpretación extrajudicial de la constitución, desafiándose la supremacía judicial; 115 incluso al punto de que algunos impugnan cualquier forma de control judicial sobre las leyes. ${ }^{116}$

en la ciudadanía de una manera bastante vaga, como veremos infra. Moreno, op. cit., p. 112 .

114 Sobre el constitucionalismo débil véase por ejemplo Bayón, "Democracia y derechos...", cit., pp. 351 y ss.

115 Cabe distinguir entre control judicial de constitucionalidad y supremacía judicial, que es la combatida por los populares. Según Kramer, esta última se refiere a la noción según la cual los jueces tienen la última palabra cuando se trata de interpretar la constitución, determinando sus decisiones el significado de la constitución para todos. Kramer, Larry, The people themselves. Popular Constitutionalism and Judicial Review, Nueva York, Oxford University Press, 2004, p. 125. Según Waldron por supremacía judicial se entiende una situación en la que (1)los tribunales resuelven temas importantes para todo el sistema político, (2) esas resoluciones son tratadas como absolutamente vinculantes para todos los otros actores del sistema político y (3) los tribunales no tienen deferencia por las posiciones tomadas sobre esos temas por las otras ramas. Waldron, "The Core of the Case against Judicial Review", cit., p. 1354, nota 22. Cabe aclarar, como veremos infra, que estas definiciones no son compartidas por todos los populares. En este sentido véase Post, Robert y Siegel, Reva, "Popular Constitutionalism, Departamentalism, and Judicial Supremacy”, California Law Review 92, 2004, pp. 1030 y 1031.

116 En este sentido vimos como Waldron se enfrenta al control judicial de constitucionalidad (especialmente el que califica de "fuerte") y también Tushnet plantea su erradicación en Taking the Constitution away from the Courts, Princeton, Nueva Jersey, Princeton University Press, 1999, p. 126. Este mismo autor hace la distinción entre formas fuertes y débiles de control judicial, prefiriendo las segundas, que se distinguirian 
Esta revista forma parte del acervo de la Biblioteca Jurídica Virtual del Instituto de Investigaciones Jurídicas de la UNAM www.juridicas.unam.mx

http://biblio.juridicas.unam.mx

ANA MICAELA ALTERIO

Este último grupo específicamente se centra en los argumentos que de forma acritica se han sostenido para justificar y asignar un lugar privilegiado o de responsabilidad final a los jueces en la interpretación constitucional. Así discuten que necesitemos de la supremacía judicial a fin de que el derecho constitucional no se vuelva inaceptablemente caótico e impredecible; que el propósito de la constitución sea el de atrincherar derechos individuales que prevengan a la ciudadanía de su propia peligrosidad a futuro (estrategia del precompromiso) y finalmente, que los tribunales sean mejores y más confiables que los cuerpos electoralmente responsables a la hora de abordar cuestiones de principios. ${ }^{117}$

Brevemente, se insiste en que no hay algo así como un acuerdo final en el derecho. ${ }^{118}$ Que los sistemas legales pueden y deben tolerar cierta incertidumbre y falta de clari $\operatorname{dad}^{119}$ y que incluso en un sistema con supremacía judicial,

porque: 1) la legislatura tiene el poder de repudiar las especificaciones (specification) - de principios constitucionales abstractos- que hace la Corte y 2) el proceso interactivo de especificación y revisión —que se da entre Corte y Legislatura- puede ocurrir en un período de tiempo relativamente corto. Tushnet, Mark, "Forms of Judicial Review as Expressions of Constitutional Patriotism", Law and Philosophy 22, Netherlands, 2003, p. 369. Aunque también desconfia de estas formas débiles dado que -en su criterio- pueden degenerar en formas de control fuertes. Véase del mismo autor "New Forms of Judicial Review and the Persistence of Rights —and Democracy - Based Worries", Wake Forest Law Review, núm. 38, 2003, pp. 813-838. En la misma línea crítica a todo tipo de revisión judicial encontramos a Levinson, Sanford, Constitutional Faith, Nueva Jersey, Princeton University Press, 1988.

117 Kramer, "Popular Constitutionalism, circa 2004", cit., p. 986.

118 Porque tampoco lo hay en la política. En esto insiste Waldron, quien niega directamente que el consenso y la uniformización tengan valor en sí mismos. Gargarella, Roberto y Martí, José Luis, "Estudio Preliminar. La filosofía del derecho de Jeremy Waldron: Convivir entre desacuerdos", en Waldron, Jeremy, Derecho y desacuerdos, cit., p. XVI.

119 En igual sentido Tushnet, Mark, "Popular Constitutionalism as Political Law", Chicago Kent Law Review81, 2006, pp. 1000, 1001, insiste especialmente en que quitar la última palabra a los jueces no desemboca en "anarquía": "People in organized societies tolerate a fair amount of uncer- 
Esta revista forma parte del acervo de la Biblioteca Jurídica Virtual del Instituto de Investigaciones Jurídicas de la UNAM www.juridicas.unam.mx

http://biblio.juridicas.unam.mx

CONSTITUCIONALISMO CONTEMPORÁNEO A DEBATE

esa incertidumbre persiste. ${ }^{120}$ Paralelamente, en sistemas sin supremacía judicial también es necesario cierto grado de finalidad y resolución. ${ }^{121}$ En suma, lo que nos dicen los populares es que si bien la claridad y la certeza son valores importantes, hay otros que lo son aun más y difícilmente querríamos asumirlos como costos en pro de los primeros. ${ }^{122}$

Por otro lado se combate la idea de atrincherar derechos en la constitución como modo de garantía ante posibles excesos de las mayorías, desmontando la noción de que esto constituiría una "autolimitación" que los propios individuos nos damos mediante mecanismos de racionalidad imperfecta para evitar los momentos de debilidad de la voluntad. ${ }^{123}$ Sobre este punto se han presentado numerosas críticas que no repetiré aquí, ${ }^{124}$ sólo me parece relevante destacar que lo que se propone es un reconocimiento del poder de las legislaturas para proveer interpretaciones constitucionales que

tainty on some questions as long as there is sufficient stability on other matters".

120 Pensemos por ejemplo en la "incertidumbre" que se genera ante un caso en el que es necesario realizar una ponderación entre principios constitucionales, como plantea el neoconstitucionalismo, incluso en sistemas con supremacía judicial; o en la falta de previsibilidad que resulta ante un cambio de criterio en la jurisprudencia.

121 Kramer, "Popular Constitutionalism, circa 2004", cit., p. 987. Los ejemplos de sistemas sin supremacía judicial que toman los populares son el de Reino Unido, Nueva Zelanda y, con reservas, el sistema canadiense.

122 Ibidem, p. 989.

123 Según explica la estrategia del precompromiso formulada por Elster, Jon, Ulises y las sirenas. Estudios sobre racionalidad e irracionalidad, trad. de Juan José Utrilla, México, Fondo de Cultura Económica, 1995 , p. 66. Aunque el propio autor luego haya reconocido que era inapropiada en Ulises desatado. Estudios sobre racionalidad precompromiso y restricciones, trad. de Jordi Mundó, Barcelona, Gedisa, 2002.

124 Véase Gargarella, Roberto, "Los jueces frente al coto vedado", Doxa. Discusiones. Publicaciones periódicas, núm. 1, 2000, pp.55 y ss.; Bayón, "Democracia y Derechos...", cit., pp. 337-339; Waldron, Derecho y desacuerdos, cit., cap. 12 . 
Esta revista forma parte del acervo de la Biblioteca Jurídica Virtual del Instituto de Investigaciones Jurídicas de la UNAM www.juridicas.unam.mx

http://biblio.juridicas.unam.mx

ANA MICAELA ALTERIO

difieran de, o alteran las interpretaciones ofrecidas por los tribunales. ${ }^{125}$ Incluso en su extremo, algunos llegan a cuestionar el hecho mismo de considerar positivo tener una carta de derechos en las constituciones. ${ }^{126}$

Las razones que Waldron nos ofrece para rechazar la constitucionalización de derechos tienen que ver, en primer lugar, con el temor hacia la rigidez verbal. Según explica el autor, las palabras suelen tomar "vida propia", convirtiéndose en un eslogan obsesivo que sirve para expresar cualquier cosa que alguien quiera decir sobre el derecho en cuestión. Esta no parece ser la mejor forma de discutir sobre cuestiones de derechos y límites al gobierno, pues limita la capacidad para desarrollar argumentos - libres del verbalismo de una determinada carta de derechos escritay de flexibilizar el discurso. ${ }^{127}$

La segunda razón que se presenta para combatir el atrincheramiento de derechos en las constituciones tiene que ver con que los vuelve inmunes al cambio legislativo. Esto, que para los neoconstitucionalistas es motivo de celebración, para los populares es preocupante, dado que implica a la vez una actitud de desconfianza hacia los conciudadanos y una arrogante seguridad en uno mismo. ${ }^{128}$ Esta acti-

125 Tushnet, "New Forms of Judicial Review and the Persistence of Rights -And Democracy-Based Worries", cit., nota 119, p. 818. Lo que resaltan sistemas como el propuesto, es la posibilidad de que existan desacuerdos interpretativos razonables entre los tribunales y las legislaturas.

126 Waldron, Derecho y desacuerdos, cit., cap. 10, del mismo autor "A Right-Based Critique of Constitutional Rights", cit., y también, ya criticando el hecho general de una constitución escrita: "Constitutionalism: A Skeptical View", cit., pp. 7 y ss.

127 Waldron, "A Right-Based Critique of Constitutional Rights", cit., pp. 26 y 27.

128 La seguridad se ve reflejada en el convencimiento de que la formulación propia refleja adecuadamente un derecho fundamental y la desconfianza implícita hacia los demás se demuestra considerando que cualquier concepción alternativa que puedan formular los legisladores electos en un momento posterior será probablemente errónea, mal dirigida o peor motivada que la propia. 
Esta revista forma parte del acervo de la Biblioteca Jurídica Virtual del Instituto de Investigaciones Jurídicas de la UNAM www.juridicas.unam.mx

http://biblio.juridicas.unam.mx

CONSTITUCIONALISMO CONTEMPORÁNEO A DEBATE

tud no casa bien con la idea de respeto por la autonomía y responsabilidad de las personas, insita en la idea de derechos que se pretenden atrincherar. ${ }^{129}$ En conclusión, Waldron nos dice que no hay nada obvio en combinar el respeto por los derechos con una desconfianza hacia las capacidades democráticas y representativas de las personas, ${ }^{130}$ por lo que habría que "liberar" la discusión de los derechos de la rigidez constitucional.

En otro plano, sin rechazar la constitucionalización de derechos, Bayón reflexiona: "La idea de que no es legítimo usar el 'derecho de autonomía pública' para decidir acerca de los derechos fundamentales, simplemente porque puede producir decisiones que los vulneren y su vulneración es injustificable, olvida precisamente que las decisiones son inevitables y que el hecho de que uno de los procedimientos de decisión posibles sea falible no puede ser por sí solo una razón suficiente para descartarlo cuando todos los demás también lo son". ${ }^{131}$ De allí también la necesidad de desmentir, por exagerada y parcial, la asunción que los jueces conformen un "foro de principios" donde se puedan abordar/interpretar mejor las cuestiones centrales del derecho constitucional. ${ }^{132}$

Así se comienza por desmitificar la idea según la cual los jueces siempre actúan sesudamente, ponderando cuestiones de principios antes de resolver y dando explicaciones cuidadosas que reflejen esa reflexión profunda acerca de los dilemas teóricos y filosóficos que enfrentan. ${ }^{133}$ A la par que

129 Idem. Es que, sigue Waldron, la atribución de derechos a los individuos tiene que ver con una visión de ellos como agentes pensantes, dotados con capacidad de reflexión y deliberación moral.

130 Ibidem, p. 28.

131 Bayón, "Democracia y Derechos...", cit., p. 312.

132 Kramer, "Popular Constitutionalism, circa 2004", cit., p. 992.

133 De hecho para Tushnet, en las condiciones en que se ejerce el control de constitucionalidad en los Estados Unidos, no se satisfacen siquiera las condiciones del diálogo necesario en una democracia constitucional. Tushnet, "Forms of Judicial Review as Expressions of Constitutional Patriotism", cit., p. 355. 
Esta revista forma parte del acervo de la Biblioteca Jurídica Virtual del Instituto de Investigaciones Jurídicas de la UNAM www.juridicas.unam.mx

http://biblio.juridicas.unam.mx

ANA MICAELA ALTERIO

se cuestiona la imagen que presenta a unos legisladores que actúan prácticamente como autómatas, incapaces de deliberar seriamente acerca de nada, que son irresponsables, emocionales, irracionales y que representan únicamente intereses privados. ${ }^{134}$ Se explica que no hay ninguna evidencia empírica para sostener que los jueces hacen un mejor trabajo que las otras ramas politicas cuando se trata de cuestiones de principios. ${ }^{135}$ Entonces, con mayor razón se tornan necesarios argumentos contundentes para quitar estas decisiones de manos de la ciudadanía. ${ }^{136}$

De fondo lo que se busca son criterios de legitimidad para la toma de decisiones de cualquier tipo, con una fuerte sospecha hacia las élites — sean éstas académicas, sociales

134 Kramer, "Popular Constitutionalism, circa 2004", cit., p. 998. Esta idea de que los tribunales deben proteger a la constitución de la corrupción de la política, o en otras palabras, proteger a la constitución de la gente, es llamada "Juricentric Constitution" por los populares. Post, Robert y Siegel, Reva, "Protecting the Constitution from the People: Juricentric Restrictions on Section Five Power", Indicana Law Journal 78, 2003, pp.1, 18 quienes la critican fuertemente.

135 Kramer, "Undercover Anti-Populism", cit., p.1352. En definitiva, se reconoce que en ambas instituciones hay una mezcla de influencias, algunas basadas en intereses y otras basadas en principios. También véase Tushnet, "Forms of judicial review as expressions of constitutional patriotism”, cit., p. 366, donde en realidad critica a Habermas y su creencia de que finalmente, los argumentos basados en derechos son más frecuentes en las cortes. Finalmente esto es reconocido por el propio Dworkin, "La lectura moral y la premisa mayoritaria”, cit., p. 132.

136 Como afirma Waldron, en una sociedad marcada por la existencia de desacuerdos profundos, y a la vez fundada sobre el principio de igualdad (entendido como igual status moral e igual capacidad de cada uno) la idea de que la reflexión sobre las cuestiones más importantes que dividen a la sociedad deba ser trasladada a los tribunales (cuyos miembros también está divididos por desacuerdos profundos y que también deciden a través de la regla mayoritaria) "parece un insulto". Waldron, Derecho y desacuerdos, cit., p. 23. En similar sentido Kramer, "Undercover Anti-Populism", cit., p. 1351 afirma "... more is required to make the theory persuasive than showing that what we are doing at this particular moment is defensible [...] At the very least, we need some sort of straight up comparison with the alternative practice and its normative justification". 
Esta revista forma parte del acervo de la Biblioteca Jurídica Virtual del Instituto de Investigaciones Jurídicas de la UNAM www.juridicas.unam.mx

http://biblio.juridicas.unam.mx

CONSTITUCIONALISMO CONTEMPORÁNEO A DEBATE

o politicas- y sus reclamos de experticia y juicio superior. ${ }^{137}$ En materia institucional, eso se traduce, además de en el aludido cuestionamiento a la idea de rigidez constitucional y de que un grupo de jueces pueda "tutelar" los intereses de la mayoría, en una preferencia por la participación popular en las estructuras políticas y económicas que afectan la vida de la ciudadanía junto a una idea de rotaciones regulares en los puestos de autoridad y poder. ${ }^{138}$

Esta reivindicación de la participación es de los intereses y las actitudes de la "gente común", con su insita indisciplina, sin mediaciones que le den forma o los "refinen", 139 aunque sin llegar tampoco a una idea romántica de ello. ${ }^{140}$ Así, frente al aislamiento o la pasividad, ${ }^{141}$ se resalta el valor de la "energía política ordinaria" (que se tratará de canalizar a través de las instituciones) a fin de hacer a los gobiernos mejores y más sensibles a las demandas de las personas a las que pretenden servir. ${ }^{142}$ Con esto se intenta desenmas-

137 Balkin, "Populism and Progressivism as Constitutional Categories", cit., p. 1945.

138 Idem.

139 Se destaca, frente a la distinción que harian los progresistas entre cultura democrática y cultura popular, que la cultura democrática es la cultura a través de la cual los ciudadanos comunes se expresan y que es "democrática" en tanto todos pueden participar en ella, es decir, en tanto es popular. Así se intenta fusionar ambos conceptos. Ibidem, pp. 1948, 1963.

140 Parker, op. cit., p. 555. Los populistas no dudan en reconocer las patologías a las que se enfrentan: entre ellas incluyen los peligros del fascismo, el anti-intelectualismo, la persecución de minorias impopulares, la exaltación de la mediocridad y una romántica exageración de las virtudes de la masa. Balkin, "Populism and Progressivism as Constitutional Categories", cit., pp. 1950-1951.

141 Propiciadas por el individualismo liberal y que serian actitudes poco saludables para la democracia, basadas en "represiones" que finalmente erosionan las libertades y las amenazan. Parker, op. cit., p. 555.

142 Ibidem, p. 556. Se insiste en que es difícil comprender la situación de los/as "otros/as" hasta que una/o no entiende sus propias diferencias con respecto a "ellos/as" y que afectan las visiones sobre el mundo. En este sentido se reclama a la academia constitucional el estar encerrada en su propio discurso profesional desde donde juzgan con desprecio las ma- 
Esta revista forma parte del acervo de la Biblioteca Jurídica Virtual del Instituto de Investigaciones Jurídicas de la UNAM www.juridicas.unam.mx

http://biblio.juridicas.unam.mx

ANA MICAELA ALTERIO

carar el prejuicio que implica el miedo a esa energía política o incluso a la influencia que las opiniones mayoritarias puedan tener en los gobiernos; prejuicio que — se afirmabusca mantener el status quo y a los gobiernos concentrados en los intereses de los más poderosos. ${ }^{143}$

De esto resulta un derecho constitucional cuya misión central es promover la regla de la mayoría, ${ }^{144}$ donde el papel de la gente no está confinado a actos ocasionales de elaboración constitucional, sino que incluye un control activo y continuo sobre su interpretación y ejecución. ${ }^{145}$ Se argumenta que los principios constitucionales y las ideas que se generan fuera de los tribunales son cruciales para expandir las posibilidades de desarrollo constitucional y para aliviar las tensiones que ocasionalmente se presentan entre el derecho constitucional y la cultura en la que éste opera. ${ }^{146}$ Para esta visión, no hay temas que estén categóricamente vedados a la regla de la mayoria. ${ }^{147} \mathrm{De}$ hecho, en un sistema ideal de regla de la mayoría cada asunto debe ser un asunto político, abierto a la controversia política”. Así, lo

nifestaciones del pueblo. Balkin, "Populism and Progressivism as Constittutional Categories", cit., p. 1953. Muchos populistas toman ideas como esta del trabajo de Cover, Robert, "The Supreme Court, 1982 Term- Foreword: Nomos and Narrative", Harvard Law Review 97, 1983, pp. 4-68, donde el autor plantea el problema de la "multiplicidad" dentro de la comunidad y de cómo los miembros de diferentes comunidades de sentido, inevitablemente generan sus propias interpretaciones de la ley, basadas en su propio nomos y en su propia narrativa. En ese marco, la tarea de los jueces no es la de crear derecho sino la de destruirlo. En sus palabras: "Judges are people of violence. Because of the violence they command, judges characteristically do not create law, but kill it [...] Confronting the luxuriant growth of a hundred legal traditions, they assert that this one is law and destroy or try to destroy the rest", p. 53.

143 Parker, op. cit., p. 570.

144 Ibidem, p. 573.

145 Kramer, "Popular Constitutionalism, circa 2004", cit., p. 959.

146 Ibidem, p. 975.

147 En igual sentido Waldron, Derecho y desacuerdos, cit., p. 362 afirma: “... todo lo que es objeto de desacuerdo de buena fe está al alcance de nuestra mano".

PROBLEMA

Anuario de Filosofia y Teoría del Derecho, Núm. 8, enero-diciembre de 2014, pp. 227-306 
Esta revista forma parte del acervo de la Biblioteca Jurídica Virtual del Instituto de Investigaciones Jurídicas de la UNAM www.juridicas.unam.mx

http://biblio.juridicas.unam.mx

CONSTITUCIONALISMO CONTEMPORÁNEO A DEBATE

que está en el centro del argumento constitucional es la controversia política acerca de la democracia. ${ }^{148}$

Pero nuevamente hay que realizar precisiones dado que lo variopinta de esta corriente se advierte principalmente en lo relativo a los arreglos institucionales. Así como es cierto que una de las notas comunes a los populares es el propiciar una interpretación extrajudicial de la constitución, no lo es en cambio el papel que asignan a los jueces ante esto. Como adelanté, algunos consideran que cualquier control de constitucionalidad debe ser combatido, pero otros no están de acuerdo con esa consecuencia. ${ }^{149}$

En este sentido Post y Siegel critican la tendencia de la Corte norteamericana de auto-designarse como autoridad exclusiva para interpretar la Constitución ${ }^{150}$ y sostienen que la interpretación y la ejecución de los derechos constitucionales depende de una relación continua y dinámica entre el Congreso y la Corte. ${ }^{151}$ Así admiten que si bien el sistema legal ha dotado a las decisiones de la Corte Suprema de "fi-

148 Parker, op. cit. pp. 578, 580.

149 Post y Siegel, "Popular Constitutionalism, Departamentalism, and Judicial Supremacy", cit. Con sus palabras: "We agree with Kramer that constitutional law must in the end find its legitimacy in the constitutional culture of nonjudicial actors. But [...] we nonetheless see a more significant role for the institution of judicial review in realizing constitutional values than does Kramer", p. 1029.

150 Post y Siegel, "Protecting the Constitution from...", cit., p. 2.

151 Post, Robert y Siegel, Reva, "Democratic Constitutionalism", en Balkin, Jack M. y Siegel, Reva (eds.), The Constitution in 2020, Nueva York, Oxford University Press, 2009, pp. 25-34, también "Roe Rage: Democratic Constitutionalism and Backlash", Harvard Civil-Rights Civil-Liberties Law Review 42, 2007, pp. 373-433. Quienes, dentro del considerado constitucionalismo popular, propician el "Constitucionalismo democrático" que viene a expresar, a su criterio, la paradoja que la autoridad constitucional dependa de su capacidad de respuesta democrática a la vez que de su legitimidad como ley (donde "ley" se entiende como algo distinto de la política) o, en otras palabras, a denominar esa "compleja e interdependiente relación entre la politica y el derecho constitucional". Post, Robert, "Theorizing Disagreement: Reconceiving the Relationship Between Law and Politics", California Law Review 98, 2010, pp. 1319- 1350; p.1345. 
Esta revista forma parte del acervo de la Biblioteca Jurídica Virtual del Instituto de Investigaciones Jurídicas de la UNAM www.juridicas.unam.mx

http://biblio.juridicas.unam.mx

ANA MICAELA ALTERIO

nalidad", sus juicios no pueden ser incorporados dentro de la propia concepción constitucional del país hasta que éstos no son acogidos por los ciudadanos fuera de la Corte. Entonces, si la participación de las ramas populares es necesaria para legitimar y ejecutar los juicios constitucionales de la Corte, esa participación puede también ser un recurso importante para las propias deliberaciones de la Corte acerca de cómo interpretar la constitución. ${ }^{152}$ Desde allí, Post y Siegel propician un diálogo constitucional inclusivo, especialmente sensible a los movimientos sociales, ${ }^{153}$ donde el pueblo debe retener la última palabra sobre el significado de la constitución, pero compatible con la idea de supremacía judicial. 154

Entre los mecanismos institucionales que el autor y la autora contemplan para enfrentar este dificil equilibrio, ${ }^{155}$ están la posibilidad de realizar enmiendas a la constitución (aunque reconocen que su uso no es frecuente); el nombramiento de los jueces de la Suprema Corte; la posibilidad de contestar normas por parte de las ramas politicas del gobierno o de los movimientos sociales, desafiando la legitimidad de los entendimientos tradicionales e incluso, lle-

152 Post y Siegel, "Protecting the Constitution from the People...", cit., pp. 31 y 32. En suma, para Post y Siegel la legitimidad de la constitución depende de una "relación de reconocimiento", donde el pueblo norteamericano, con sus diferentes identidades, debe sentir que la Constitución es expresión suya, reconocerla como propia. Post y Siegel, "Democratic Constitutionalism", cit., p. 27.

153 Sobre el papel central de los movimientos sociales a la hora de influir en las interpretaciones constitucionales de las élites, véase M. Balkin, Jack, "The Constitution of Status", The Yale Law Journal 106, 1996-1997, pp. 2313-2374, especialmente pp. 2338 y ss.

154 Post y Siegel, "Popular Constitutionalism, Departamentalism, and Judicial Supremacy", cit., p. 1029. Esa compatibilidad se lograría mediante un balance viable entre ambos propósitos.

155 Vale aclarar que el análisis que abordan es positivo, circunscrito al derecho constitucional norteamericano y no normativo. Post y Siegel, "Democratic Constitutionalism", cit., pp. 26 y ss., aunque se puedan transpolar sus tesis para pensar nuestros sistemas legales. 
Esta revista forma parte del acervo de la Biblioteca Jurídica Virtual del Instituto de Investigaciones Jurídicas de la UNAM www.juridicas.unam.mx

http://biblio.juridicas.unam.mx

CONSTITUCIONALISMO CONTEMPORÁNEO A DEBATE

gando a desobedecer las decisiones judiciales. ${ }^{156}$ Estos mecanismos, como vimos, no son considerados suficientes para el grupo de autores analizado en primer término, ${ }^{157}$ principalmente porque presuponen un largo período de tiempo hasta que se pueda revertir una decisión de la Corte cambiando su composición o tratando - aunque el tiempo pueda ser menor- de influenciar a sus miembros para que cambien de opinión. En definitiva lo que revelan es que un proceso de diálogo así pensado, termina cuando la propia Corte viene a estar de acuerdo con sus adversarios, otorgándole una prioridad normativa sobre sus interlocutores $^{158}$ que ya vimos, para la mayor parte de los populares no es justificable.

3. ¿Qué teoría de la democracia?

A esta altura ya el lector o la lectora podrá haber notado los contrastes con la teoría de la democracia "sustancial" que se dijo sostienen los neoconstitucionalistas, incluso con el tipo de teorias deliberativas alli esbozadas. De todos modos, recapitularé sintéticamente los puntos más destacables para el constitucionalismo popular. Como expone Gargarella, éste parte de la premisa según la cual "el gobierno pertenece al pueblo (antes que a sus representantes, y mucho antes que a la justicia)...”. ${ }^{159}$

156 Post y Siegel, "Popular Constitutionalism, Departamentalism, and Judicial Supremacy”, cit., p. 1039.

157 Por ejemplo Kramer, "Undercover Anti-Populism", cit., p. 1344 expresa: "To someone who embraces popular constitutionalism, it is not enough to say that ordinary citizens can change the text through amendment, whether under the process specified in Article V or via some more informal route, since the undoubted popular authority to make constitutional law neither diminishes nor excludes any concurrent power to interpret it".

158 Tushnet, "Popular constitutionalism as political law", cit., pp. 998 y 999.

159 Gargarella, "El nacimiento del constitucionalismo popular...", cit. 
Esta revista forma parte del acervo de la Biblioteca Jurídica Virtual del Instituto de Investigaciones Jurídicas de la UNAM www.juridicas.unam.mx

http://biblio.juridicas.unam.mx

ANA MICAELA ALTERIO

Frente al aludido valor técnico que los neoconstitucionalistas daban a la regla de la mayoría, los populares le otorgan un valor axiológico. ${ }^{160}$ Así por ejemplo Waldron, sostiene que el principio de la regla de la mayoría respeta de una forma única la igual autoridad política de cada individuo,161 por tanto en ésta debe residir el criterio último de legitimidad democrática. Para este autor, la regla de las mayorias no sólo es una solución pragmática a las circunstancias de la política; es la única que además, visto los desacuerdos, es neutral al cambio o a la conservación del estado de cosas.

Esto no significa que los populares sostengan que la democracia se circunscribe a la regla de la mayoria, puesto que también la conciben como una teoría acerca de la organización apropiada de la sociedad y de las relaciones sociales. ${ }^{162}$ Así se asocia directamente a la idea de "cultura democrática", 163 que viene a complementar los rasgos meramente formales de la democracia a fin de desmantelar las jerarquías injustas que permanecen en su interior. ${ }^{164} \mathrm{La}$ forma en que esta cultura popular se manifiesta es a través de los movimientos sociales que tornan visibles esas injusticias y promueven el cambio social. Por lo mismo, tampoco es adecuado afirmar que los populares consideren que "la interpretación constitucional debe ser "mayoritaria", 165 sino

160 Véase nota 65. En esa línea, se denuncia la confusión que los "progresistas" realizan entre capacidad técnica y capacidad moral para quitarle poder a la "gente común". Balkin, "Populism and Progressivism as Constitutional Categories", cit., p. 1951.

161 Waldron, "Deliberación, desacuerdo y votación”, cit., p. 265.

162 Balkin, "The Constitution of Status", cit., p. 2368.

163 Ibidem, p. 2314.

164 Ibidem, p. 2367. Balkin retoma aquí el análisis de la famosa nota al pie núm. 4 de la sentencia "Carolene products" que en su momento estudiara John Hart Ely sobre las minorias discretas e insulares.

165 Gargarella, Roberto, "Acerca de Barry Friedman y el "constitucionalismo popular mediado"”, Revista Juridica de la Universidad de Palermo, año 6, núm. 1, 2005, p. 164: "entendiendo por mayoritaria la idea populista según la cual la interpretación debe seguir de modo más o menos in- 
Esta revista forma parte del acervo de la Biblioteca Jurídica Virtual del Instituto de Investigaciones Jurídicas de la UNAM www.juridicas.unam.mx

http://biblio.juridicas.unam.mx

CONSTITUCIONALISMO CONTEMPORÁNEO A DEBATE

más bien lo que propugnan es que detrás de ella haya una teoria acerca de lo que es la democracia'166 y que en última instancia, se deje a la voluntad consistente y deliberada del pueblo, la última palabra. ${ }^{167}$

Esta afirmación final nos permite acercar a los populares - con reservas - a algunas versiones del modelo de la "democracia deliberativa"168 que colocan al desacuerdo en el centro de su teoría ${ }^{169}$ y por ello la consideran un proyecto inacabado, signado por el conflicto y en cambio permanente. ${ }^{170}$ Para esta visión, la atención debe ponerse en la igualdad de oportunidades a la hora de acceder al proceso politico y expresarse ${ }^{171}$ y no en las formas de esa expresión, su calidad o precondiciones. Así, por ejemplo con respecto a las legislaturas, se afirma que si bien no operan en una especie de situación ideal de diálogo de tipo habermasiana, eso no quiere decir que el proceso legislativo no sea deliberativo o provisto de principios. ${ }^{172}$

Este grupo de pensadores, en general, tiene la convicción de fondo de que la democracia tiene un valor moral que el

mediato, irreflexivo, incuestionado, las ocasionales preferencias que sostenga una particular mayoría social, en un momento determinado".

166 Balkin, "The Constitution of Status", cit., p. 2372. Con sus palabras: "This theory requires, among other things, a theory of what democracy was".

167 Gargarella, “Acerca de Barry Friedman y el "constitucionalismo popular mediado"”, cit., p. 165.

168 Aunque no a aquellas de tinte "liberal" asociadas al elitismo, que mencionara en nota 72 in fine.

169 En este sentido Waldron, Derecho y desacuerdos, cit., p. 113. Para este autor entonces "el mejor modelo de democracia será aquel que integre o ensamble su reconstrucción del elemento de la deliberación con la reconstrucción del elemento del voto y la regla de la mayoria". Gargarella, y Martí, "Estudio preliminar", cit., p. XL.

170 Balkin, "The Constitution of Status", cit., p. 2314. Aunque este autor afirma que el modelo de democracia populista no es el de un diálogo prolongado, sino el de "revoluciones periódicas" en "Populism and Progressivism as Constitutional Categories”, cit., p. 1988.

171 Ibidem, p. 1969.

172 Kramer, "Undercover Anti-Populism”, cit., p. 1357. 
Esta revista forma parte del acervo de la Biblioteca Jurídica Virtual del Instituto de Investigaciones Jurídicas de la UNAM www.juridicas.unam.mx

http://biblio.juridicas.unam.mx

ANA MICAELA ALTERIO

constitucionalismo no posee. ${ }^{173}$ Reconocen la importancia de los derechos fundamentales pero impugnan la idea de insertarlos en una constitución rígida que los sustraiga de la deliberación democrática, pues según creen, la mejor manera de proteger los derechos es dejándolos en manos de la ciudadanía. Lo que en suma se reivindica es un "derecho fundamental a la democracia", que es un derecho a participar en condiciones de igualdad en las decisiones sociales sobre las cuestiones más importantes de principios. ${ }^{174}$

\section{La relación entre derecho y politica}

Al contrario que las corrientes neoconstitucionalistas, los constitucionalistas populares reivindican una relación estrecha y de mutua interdependencia entre derecho y politica, ${ }^{175}$ subrayando de hecho que la constitución es un tipo especial de ley por ser una "ley politica". ${ }^{176}$

Desde el punto de vista interno, que la constitución sea una "ley" significa que es en cierto grado "retrospectiva", es decir, que su análisis involucra un ejercicio de interpretación de textos, precedentes y prácticas pasadas; pero que sea una ley "política" implica un cierto carácter "prospectivo", o sea, un ejercicio acerca de lo que se juzga será mejor para la sociedad en adelante, sin especial referencia a even-

173 Criticándose una visión del "constitucionalismo" que no se concibe sólo como una teoría normativa sobre las formas y procedimientos de gobierno, sino sobre el control, limites y restricciones al poder del Estado. Waldron, "Constitutionalism: A Skeptical View", cit., pp. 12 y 13.

174 Waldron, "A Right-Based Critique of Constitutional Rights", cit., pp. 20, 36.

175 Rechazando a su vez la distinción que se hace entre derecho y politica sobre la base de que el derecho consiste en "la razón" y por tanto es "principialista", mientras que la politica es pura voluntad y poder. Veáse Post, "Theorizing Disagreement: Reconceiving the Relationship Between Law and Politics", op. cit., pp. 1325 y ss.

176 Tushnet, "Popular Constitutionalism as Political Law", cit., p. 991. 
Esta revista forma parte del acervo de la Biblioteca Jurídica Virtual del Instituto de Investigaciones Jurídicas de la UNAM www.juridicas.unam.mx

http://biblio.juridicas.unam.mx

CONSTITUCIONALISMO CONTEMPORÁNEO A DEBATE

tos pasados. ${ }^{177}$ Esto quiere decir que no se puede pensar en la "aplicación" de la constitución en términos técnicos, como un acto "cognitivo" de mera constatación y subsunción, ${ }^{178}$ carente de decisión. La constitución debe verse también como una herramienta de empoderamiento, es decir, la constitución establece instituciones que permiten a la gente coordinar y cooperar en proyectos que no podrian lograr por sí mismosit9 en el marco de desacuerdos permanentes. 180

Podría pensarse que también algunos neoconstitucionalistas tienen en cuenta este carácter "prospectivo" de la constitución cuando celebran el hecho de que ésta esté compuesta por principios que deberán aplicarse a cada caso según sus particularidades. ${ }^{181}$ Pero la gran diferencia se encuentra a la hora de determinar quién tiene el poder de decidir sobre la configuración de estas posibilidades. Vimos que el neoconstitucionalismo deja en manos de los jueces la decisión última, negándole el carácter de política y disfrazándola de tecnicismos como la "ponderación". ${ }^{182}$ En cambio los populares insisten en que sea "el pueblo" el que vaya configurando el derecho constitucional como ley política a través de sus movilizaciones politicas. ${ }^{183}$ Esto se lleva a

177 Ibidem, pp. 992 y 993. Post y Siegel, "Popular Constitutionalism, Departmentalism, and Judicial Supremacy”, cit., pp. 1037 y 1038 realizan una distinción similar entre "constitutional law" y "Constitution" donde la primera reflejaría las opiniones de la Corte y la segunda - más importante- expresaría las creencias fundamentales de "nosotros el pueblo". Entre estas dos nociones habría una relación dialéctica que debería tender al equilibrio.

178 Como lo hace Ferrajoli, Principia Iuris, cit., t. I, pp. 530-534, 832 y 833; t. II, p.75.

179 Waldron, “Constitutionalism: A Skeptical View”, cit., p. 20.

180 En igual sentido, Post, op. cit., pp. 1336 y ss.

181 Véase ut supra la posición de Ruiz Manero en nota 84.

182 De esta manera, claro está, no tienen que lidiar con los problemas de falta de legitimidad (en términos ético-político democráticos) y control del poder judicial.

183 Tushnet, "Popular constitutionalism as political law", cit., p. 994. Aquí por movilizaciones políticas y populares no se entiende necesaria- 
Esta revista forma parte del acervo de la Biblioteca Jurídica Virtual del Instituto de Investigaciones Jurídicas de la UNAM www.juridicas.unam.mx

http://biblio.juridicas.unam.mx

ANA MICAELA ALTERIO

cabo a través de un diálogo entre las distintas ramas del gobierno y la gente ${ }^{184}$ que permite hablar de "the living constitution" (la constitución viva) como sensible al, y garante del cambio social. ${ }^{185}$

Hago referencia al punto de vista interno porque lo que está en juego es la interpretación/concreción de las posibilidades del texto constitucional positivizado; sin embargo, estas mismas movilizaciones pueden estar pugnando por una modificación del texto constitucional, en cuyo caso el análisis pasa a ubicarse en el punto de vista externo. La única forma de contemplar el ingreso de estas reivindicaciones críticas a la discusión política, es pensar en constituciones flexibles y recuperar el concepto de soberanía popular que, vimos, el neoconstitucionalismo pretende superado. Esto es lo que auspicia sobre todo Waldron cuando se posiciona contra el hecho mismo de que haya una carta de derechos escrita para así permitir la discusión política de los temas más importantes para una sociedad, sin ataduras de ningún tipo. ${ }^{186}$

Así, el constitucionalismo popular recupera la noción de constitucionalismo "político", frente al hoy dominante constitucionalismo "jurídico" 187 en el que se centran los neoconstitucionalistas. Para concluir podría decirse con Bellamy que mientras el constitucionalismo jurídico (o "legal") se identifica con dos presupuestos: el de la posibilidad de

mente las que se desarrollan fuera de las instituciones, sino también los que están "mediadas" por las instituciones politicas, como puede ser el poder ejecutivo o legislativo.

184 Ibidem, p. 997.

185 Véase Post y Siegel, "Democratic Constitutionalism", cit., p. 25.

186 Este modelo se condeciría, en términos de Tushnet, con una "supremacía parlamentaria liberal", donde la cultura politica reconoce para sus debates sólo límites morales o compromisos culturales implícitos; por contraposición a una parlamentarismo "constreñido", donde las restricciones son escritas, por lo tanto los debates se centran en el significado de los documentos relevantes. Tushnet, "New Forms of Judicial Review and the Persistence of Rights- And Democracy- Based Worries", cit., p. 816.

187 Kramer, "Popular Constitutionalism, circa 2004", cit., p. 959. 
Esta revista forma parte del acervo de la Biblioteca Jurídica Virtual del Instituto de Investigaciones Jurídicas de la UNAM www.juridicas.unam.mx

http://biblio.juridicas.unam.mx

CONSTITUCIONALISMO CONTEMPORÁNEO A DEBATE

un consenso racional sobre resultados sustantivos y el de considerar al proceso judicial como más seguro a la hora de identificar dichos resultados; el constitucionalismo "politico" se condice con un enfoque más centrado en los procedimientos, dado que presupone un desacuerdo razonable sobre los resultados sustantivos y que el procedimiento democrático posee mayor legitimidad y resulta más eficaz que el proceso judicial a la hora de resolver tales desacuerdos. ${ }^{188}$ Evidentemente, en las constituciones existen elementos tanto del constitucionalismo jurídico como del político, la advertencia es no olvidarlo.

\section{El NUEVO CONSTITUCIONALISMO LATINOAMERICANO}

Como anticipé en la introducción de este ensayo, es difícil definir al nuevo constitucionalismo latinoamericano, incluso determinar el momento de su surgimiento o los países que estarian vinculados a alguna forma de éste. La mayor parte de los autores que se han dedicado a su estudio coinciden en unos "rasgos identificadores"189 o "tendencias comunes" 190 de los procesos constituyentes desarrollados en "buena parte de los países de la región, desde los finales del

\footnotetext{
188 Bellamy, Richard, Constitucionalismo politico. Una defensa republicana de la constitucionalidad de la democracia, trad. de Jorge Urdánoz Ganuza y Santiago Gallego Aldaz, Madrid, Marcial Pons, 2010, pp. 19-23. Por esto expresa: "Debido a que los desacuerdos que la gente mantiene sobre la justicia politica son testarudos y a que se modifican conforme sus ideales y preocupaciones cambian según se van adaptando a las circunstancias, el proceso constituyente necesita ser entendido como un proceso político continuo", p. 123.

189 Pazmiño Freire, Patricio, "Algunos elementos articuladores del nuevo constitucionalismo latinoamericano", Cuadernos Constitucionales de la Cátedra Fadrique Furió Cerol, núm. 67/68, p. 27.

190 Uprimny, Rodrigo, "Las transformaciones constitucionales recientes en América Latina: tendencias y desafios", en Rodriguez Garavito, César (coord.), El derecho en América Latina. Un mapa para el pensamiento jurídico del siglo XXI, Buenos Aires, Siglo XXI, 2011, p. 110, disponible en www.igualitaria.org.
} 
Esta revista forma parte del acervo de la Biblioteca Jurídica Virtual del Instituto de Investigaciones Jurídicas de la UNAM www.juridicas.unam.mx

http://biblio.juridicas.unam.mx

ANA MICAELA ALTERIO

siglo XX hasta nuestros dias". ${ }^{191}$ Esto hace que se considere que, a pesar de que el nuevo constitucionalismo latinoamericano carece de una cohesión y una articulación como sistema cerrado de análisis y como propuesta de modelo constitucional, "se trata de una corriente constitucional en período de construcción doctrinal". 192

A fin de clarificar entonces el objeto de atención de este apartado consideraré parte del nuevo constitucionalismo latinoamericano sólo a las constituciones que comparten un conjunto de rasgos marcados y que tienen una orientación o pretensión política particular, como lo son las de Venezuela de 1999, la de Ecuador de 2008 y la de Bolivia de 2009.193 Y si bien lleva razón Salazar cuando distingue los fenómenos constitucionales que se dan en estos países -y que se acercan más o menos a un modelo constitucional (es decir, a un conjunto de instituciones) - de la teoría para dar cuenta de ellos; ${ }^{194}$ aquí, siguiendo la idea de De Sousa Santos sobre la necesidad de una teoría de "retaguardia", ${ }^{195}$ o que vaya acompañando los procesos transformadores más que iluminándolos, abstraeré las cuestiones normativas que me interesan tanto de la práctica constitucional como de la teoría que eventualmente se haya desarrollado para explicarla, cuestionarla y compararla, nombrándolas indistintamente como nuevo constitucionalismo latinoame-

191 Gargarella, Roberto, "El nuevo constitucionalismo latinoamericano: promesas e interrogantes", p. 1 en http://www.palermo.edu/Archivos_ content/derecho/pdf/Constitucionalismo_atinoamericano.pdf.

192 Viciano y Martínez, op. cit., p. 20.

193 Salazar "El nuevo constitucionalismo latinoamericano", cit, p. 350 (aunque también puedan distinguirse algunos de estos rasgos en otras constituciones o prácticas constitucionales). A estos procesos se los califica también de "rupturistas", véase Viciano y Martínez, op. cit., p. 30, o "transformadores" según la expresión de Santos, Boaventura de Sousa, Refundación del Estado en América Latina. Perspectivas desde una epistemología del sur, México, Siglo XXI, Siglo del Hombre Editores, Universidad de los Andes, 2010, pp. 85 y ss.

194 Salazar, "El nuevo constitucionalismo...", cit, pp. 351 y 352.

195 De Sousa Santos, Boaventura, op. cit, p. 38. 
Esta revista forma parte del acervo de la Biblioteca Jurídica Virtual del Instituto de Investigaciones Jurídicas de la UNAM www.juridicas.unam.mx

http://biblio.juridicas.unam.mx

CONSTITUCIONALISMO CONTEMPORÁNEO A DEBATE

ricano. Es que en este caso, coincido con Garavito en que no puede dibujarse una línea entre teoría y práctica, ni un acabado círculo, sino una espiral sin fin. ${ }^{196}$

Como explica Gargarella, el constitucionalismo siempre apareció asociado a la necesidad de poner fin a un cierto mal. ${ }^{197}$ En el caso de las nuevas constituciones bajo análisis, podría decirse que ese mal tiene que ver con la marginación político-social de ciertos grupos, (especialmente el caso de los indígenas) ${ }^{198}$ y con la desigualdad social resultado de la aplicación de políticas neoliberales, particularmente durante la década de los ochenta. ${ }^{199}$ Ese será el fin a tener presente para evaluar esta corriente de pensamiento y para compararla con las que vimos anteriormente.

Un abordaje distinto nos propone Salazar, quien analiza el nuevo constitucionalismo latinoamericano desde la perspectiva de la teoría constitucional (clásica), teniendo como referencia el modelo democrático constitucional ${ }^{200}$ y desde donde rescata postulados claves como la pretensión de brindar certeza y seguridad jurídica a las personas para realizar la valoración. ${ }^{201}$ Este tipo de análisis, que es bastante habitual, adolece - desde mi punto de vista- de algunos problemas. Para empezar selecciona unos principios

196 Rodríguez Garavito, Cesar, "Prólogo. Teorías de retaguardia: la refundación del Estado, el derecho y la teoría social en América Latina", en Sousa Santos, Boaventura de, Refundación del Estado en América Latina. Perspectivas desde una epistemología del sur, cit., p. 13.

197 Gargarella, "El nuevo constitucionalismo latinoamericano", cit., p. 1.

198 Ibidem, p. 2, aludiendo claramente al caso de la constitución boliviana. En igual sentido Perez Calvo, Alberto, "Características del nuevo Constitucionalismo latinoamericano", en Storini, Claudia y Alenza García, José Francisco (dirs.), Materiales sobre neoconstitucionalismo y nuevo constitucionalismo latinoamericano, Navarra, Aranzadi, 2012, p. 29.

199 Viciano y Martínez, op. cit., pp. 21 y 22.

200 Que es el que, según el propio autor, "maduró en occidente sobre todo después de la Segunda Guerra Mundial” y que es al que se adscribe el neoconstitucionalismo, que como aquí enuncié, abarca tanto al neoconstitucionalismo normativo (o garantismo según el desarrollo de Ferrajoli) como al conceptual o neoconstitucionalismo propiamente dicho.

201 Salazar, "El nuevo constitucionalismo latinoamericano", cit., p. 348. 
Esta revista forma parte del acervo de la Biblioteca Jurídica Virtual del Instituto de Investigaciones Jurídicas de la UNAM www.juridicas.unam.mx

http://biblio.juridicas.unam.mx

ANA MICAELA ALTERIO

como medida de evaluación que no son los que el nuevo constitucionalismo latinoamericano prioriza. ${ }^{202}$ Pero además, tiene como punto de partida un modelo de constitucionalismo que es en sí altamente polémico y con el que justamente aquí estamos intentando contrastar. Evidentemente no se puede usar como parámetro de medida para analizar un modelo alternativo, al propio modelo democrático constitucional de tipo europeo del que el primero se trata de distinguir. Así la crítica se desvanece en tanto las falencias que se encuentren al nuevo constitucionalismo latinoamericano estarán supeditadas a la aceptación de la perspectiva que éste pretende transformar. ${ }^{203}$

Dicho esto, para continuar con la dinámica de confrontación entre las corrientes indicadas, hay que dejar sentado que el nuevo constitucionalismo latinoamericano pretende ser plenamente normativo y por tanto constituir un Estado Constitucional.204 Es por ello que se puede decir que su

202 Como vimos, tampoco son los más importantes para el constitucionalismo popular, véase Kramer, "Popular Constitutionalism, circa 2004", cit., p. 989, citado en nota 122 .

203 Se afirma en esta lógica que el nuevo constitucionalismo latinoamericano pretende transformar las bases propietaristas y de lejanía elitista de la representación que atribuye al constitucionalismo (clásico). Véase Palacios Romeo, Francisco, "La reivindicación de la polis: Crisis de la representación y nuevas estructuras constitucionales de deliberación y participación en Latinoamérica", en Storini y Alenza, Materiales sobre neoconstitucionalismo y nuevo constitucionalismo latinoamericano, cit., p. 240. También que expresamente rechaza la tradición constitucional individualista y elitista. Detlef Nolte y Almut Schilling- Vacaflor, "Introduction: The Times they are a Changin': Constitutional Transformations in Latin America since the 1990s”, en Detlef Nolte y Almut Schilling-Vacaflor (eds.), New Constitutionalism in Latin America. Promises and Practices, Inglaterra, Ashgate, 2012, p. 23. Hay que decir de todos modos que el propio Salazar advierte esta dificultad cuando afirma que "las objeciones... que han sido desarrolladas..., en cierta medida, quedarían compensadas en la dimensión política del NCL", Salazar, "El nuevo constitucionalismo latinoamericano", cit., p. 367.

204 Aunque con nuevas nomenclaturas que tienen por fin el enfatizar la búsqueda propia de fórmulas constitucionales, como "Estado democrático y social de Derecho y de Justicia...” según la constitución de Venezuela 
Esta revista forma parte del acervo de la Biblioteca Jurídica Virtual del Instituto de Investigaciones Jurídicas de la UNAM www.juridicas.unam.mx

http://biblio.juridicas.unam.mx

CONSTITUCIONALISMO CONTEMPORÁNEO A DEBATE

principal objetivo es la "constitucionalización del ordenamiento jurídico". ${ }^{205}$ A la vez, el nuevo constitucionalismo latinoamericano supera el concepto de constitución como limitadora del poder (constituido) y avanza en la definición de ésta como fórmula democrática donde el poder constituyente expresa su voluntad. ${ }^{206}$ En ese sentido se podrian señalar notas en común con el constitucionalismo popular como la apertura a una interpretación extrajudicial de la constitución, la democratización y participación en las instituciones políticas y económicas y la recuperación de la relación entre derecho y política.

Entonces, como se hizo en los apartados anteriores, circunscribiré mi análisis del nuevo constitucionalismo latinoamericano al tipo de legitimidad al que se afilia (1) los arreglos institucionales que propone, (2) la teoría de la democracia que subyace, y (3) la relación que establece entre derecho y politica, (4), consciente de que muchas otra cuestiones quedarán pendientes para otra oportunidad.

\section{El modelo de legitimidad}

No es necesario repetir aquí las notas que caracterizan los distintos modelos de legitimidad. Considero que el nuevo constitucionalismo latinoamericano se adscribe a un modelo procedimentalista débil. Es procedimentalista en

en su artículo 2; o "Estado constitucional de derechos y justicia, social, democrático, soberano, independiente, unitario, intercultural, plurinacional y laico." para el artículo 1 de la constitución de Ecuador o “...Estado Unitario Social de Derecho Plurinacional Comunitario, libre, independiente, soberano, democrático, intercultural, descentralizado y con autonomía" según el artículo 1o. de la Constitución boliviana.

205 Viciano y Martínez, op. cit., p. 15; citando la concepción de Guastini que he estado utilizando, véase supra nota 17 . De más está decir que el cumplimiento de las condiciones de constitucionalización es independiente de los contenidos específicos de las constituciones de los Estados, que son sin duda lo que distinguen a las estudiadas y le dan una nota de originalidad respecto a otros ordenamientos constitucionalizados.

206 Ibidem, p. 16. 
Esta revista forma parte del acervo de la Biblioteca Jurídica Virtual del Instituto de Investigaciones Jurídicas de la UNAM www.juridicas.unam.mx

http://biblio.juridicas.unam.mx

ANA MICAELA ALTERIO

tanto y en cuanto pone al centro de su legitimidad el origen democrático de la constitución, es decir al poder constituyente soberano encarnado en el pueblo.207 Esto en clara oposición a las corrientes neoconstitucionalistas que, como vimos, "demuelen" el concepto mismo de soberanía. ${ }^{208}$

A este poder constituyente "revolucionario" se le confió la reconstrucción del Estado y la sustitución de la continuidad constitucional, ${ }^{209}$ pero sin diluirse una vez cumplida su misión. ${ }^{210}$ Así se le otorga una primacia ${ }^{211}$ que, sobre todo, se ve reflejada en los procedimientos de reforma constitucional que no encuentran limitaciones de tipo sustantivo. En este sentido es ejemplificativo el texto de la constitución de Venezuela que en su artículo 347 establece:

207 Ibidem, pp. 20, 25.

208 En términos de Zagrebelsky, El derecho dúctil, cit., p. 12. Lo mismo sostiene Ferrajoli como se señaló supra. Según Villabella Armengol, Carlos Manuel, "El derecho constitucional del siglo XXI en Latinoamérica: un cambio de paradigma", en Viciano Pastor, Roberto (ed.), Estudios sobre el nuevo constitucionalismo latinoamericano, cit., p.74, justamente la legitimidad democrática del nuevo constitucionalismo (junto a su valor instrumental), esboza la distancia con el neoconstitucionalismo de factura europea. Por eso fueron posibles estas nuevas constituciones aún en ausencia de previsiones constitucionales que previeran su propia sustitución. En este punto véase Prieto Valdés, Martha, "El nuevo constitucionalismo latinoamericano: nuevos paradigmas politico constitucionales" en Viciano (ed.), Estudios sobre el nuevo constitucionalismo latinoamericano, cit., p. 98.

209 Viciano y Martínez, op. cit., pp. 32, 35 y 37.

210 Noguera Fernandez, Albert, "What do we Mean When we Talk about "Critical Constitutionalism"? Some Reflections on the New Latin American Constitutions", en Nolte y Schilling (eds.), New Constitutionalism in Latin America. cit., p. 102; por esto el nuevo constitucionalismo latinoamericano se enrolaría dentro del 'constitucionalismo crítico'.

211 Salazar, "El nuevo constitucionalismo latinoamericano", cit, p. 372, esta primacía se vería manifestada en: a) la extensión de las constituciones; b)la supremacía del documento; c) las restricciones democráticas al control de constitucionalidad; d) los mecanismos de democracia participativa o directa; e) la rigidez constitucional. 
Esta revista forma parte del acervo de la Biblioteca Jurídica Virtual del Instituto de Investigaciones Jurídicas de la UNAM www.juridicas.unam.mx

http://biblio.juridicas.unam.mx

CONSTITUCIONALISMO CONTEMPORÁNEO A DEBATE

E1 pueblo de Venezuela es el depositario del poder constituyente originario. En ejercicio de dicho poder, puede convocar una Asamblea Nacional Constituyente con el objeto de transformar el Estado, crear un nuevo ordenamiento jurídico y redactar una nueva Constitución. ${ }^{212}$

Ahora bien, esta soberanía sin límites del poder constituyente y confianza en la voluntad del pueblo, no tiene un correlato para con los poderes constituidos. ${ }^{213}$ Estos últimos más bien se hayan sujetos a fuertes restricciones constitucionales que hacen que la legitimidad en la toma de sus decisiones esté más cercana al sustancialismo (débil). Prueba de ello son las densas cartas de derechos establecidas en las constituciones y las garantías jurisdiccionales establecidas para su efectiva realización; así como el fuerte proyecto político que el Estado se compromete a realizar y de cuyos fines no puede apartarse.

Estas distintas formas de legitimidad se hallan de todos modos unidas por el establecimiento de la participación ciudadana como eje del sistema político institucional, lo que explica las particularidades en los arreglos institucionales que veremos infra.

\section{Los arreglos institucionales del nuevo constitucionalismo latinoamericano}

Éste es sin duda el capítulo más novedoso y ecléctico de la corriente en estudio. Ante todo decir que los diseños institucionales del nuevo constitucionalismo latinoamericano se pueden adscribir fácilmente al constitucionalismo fuer-

\footnotetext{
212 La cursiva me pertenece. En la misma lógica los artículos 444 de la Constitución de Ecuador y 411 de la Constitución boliviana.

213 Se establece "la prohibición constitucional de que los poderes constituidos (incluido el poder constituyente constituido) dispongan de la capacidad de reforma constitucional por ellos mismos". Viciano y Martínez, op. cit., pp. 42 y 43.
} 
Esta revista forma parte del acervo de la Biblioteca Jurídica Virtual del Instituto de Investigaciones Jurídicas de la UNAM www.juridicas.unam.mx

http://biblio.juridicas.unam.mx

ANA MICAELA ALTERIO

te $^{214}$ aunque no elitista. ${ }^{215}$ Lo primero, que lo acerca a modelos neoconstitucionalistas, se ve reflejado en la previsión de constituciones rígidas, con control judicial de constitucionalidad de las leyes "fuerte". Lo segundo, que lo acercaría a modelos propios del constitucionalismo popular, se nota en el protagonismo que se le da a la participación popular. ${ }^{216}$ Esa participación va mucho más allá del acto constituyente o de la elección de representantes, pues se prodiga a lo largo de los textos constitucionales en ámbitos como la iniciativa popular, legislativa y constitucional o el referendo aprobatorio, consultivo, revocatorio y abrogatorio. ${ }^{217}$ También se refleja en instancias ciudadanas de control de la gestión pública y en el reconocimiento de formas de democracia comunitaria desarrollada por los pueblos indígenas. ${ }^{218}$ Finalmente, no se agota en las instancias formales, sino que

214 Uprimny, Rodrigo, op. cit., p. 124.

215 De hecho hay una voluntad expresa de "trascender el constitucionalismo de élites hacia un constitucionalismo popular", Viciano y Martínez, op. cit., p. 42. Como expresan Detlef Nolte y Almut Schilling- Vacaflor, "Introduction", op. cit., p. 19 "It would be mistaken to describe the constitutional changes of Venezuela, Bolivia and Ecuador simply as top-down processes; this would not do justice to their multi-faceted nature. ...The aforementioned constitutions were perceived as instruments to reconfigure the relationships between the state and citizens ...the adoption of the new constitutions was part of bottom-up process, including legal mobilization, and was among the central demands of social movements and citizens that were discontent with the previous social and political order".

216 Al punto que se hable de estas Constituciones casi como de "orgias participacionistas", véase Palacios, op. cit., p. 177, en alusión a la Constitución ecuatoriana.

217 Pisarello, "El nuevo constitucionalismo latinoamericano y la Constitución venezolana de 1999", p.10, disponible en http://www.rebelion. org/docs/96201.pdf. Por ejemplo, la constitución venezolana en su artículo 70 prevé la participación ciudadana en la elección de cargos públicos, el referendo, la consulta popular, la revocatoria del mandato, las iniciativas mencionadas, el cabildo abierto y la asamblea de ciudadanos y ciudadanas. En Ecuador, los artículos 103-113 consagran la consulta popular y la revocatoria del mandato.

218 Véase Uprimny, cit., p. 117, también Santos, op. cit, pp. 118-122, en lo que se llama democracia intercultural. 
Esta revista forma parte del acervo de la Biblioteca Jurídica Virtual del Instituto de Investigaciones Jurídicas de la UNAM www.juridicas.unam.mx

http://biblio.juridicas.unam.mx

CONSTITUCIONALISMO CONTEMPORÁNEO A DEBATE

surge también de la previsión de mecanismos informales de participación como el derecho de resistencia. ${ }^{219}$

Ahora bien, esta cercanía con otras corrientes constitucionales no quita su fuerte originalidad, 220 en tanto el nuevo constitucionalismo latinoamericano refleja la voluntad de refundar ese legado en clave republicano democrática con el objeto de dar respuesta a alguno de los principales retos que el siglo XXI plantea a la región. ${ }^{221}$ Veamos.

Ya adelanté que la previsión de rigidez constitucional es bien distinta a la sostenida por las constituciones propias del neoconstitucionalismo, en tanto aquí la rigidez es plenamente aplicable a los poderes constituidos, mas para el poder constituyente (originario) no existen cotos vedados ni ámbitos indecidibles. Tampoco el control de constitucionalidad puede asimilarse sin más a sus pares europeos, puesto que el nuevo constitucionalismo latinoamericano se ha tomado en serio la objeción democrática y ha intentado salvarla de diversas maneras. En ese orden de ideas ha establecido la posibilidad de proponer así como de objetar candidatos al máximo Tribunal Constitucional, ${ }^{222}$ incluso en el caso de Bolivia, se prevé la elección directa de sus miembros por parte de la ciudadanía. ${ }^{223}$ Asimismo se determinan expresamente los criterios de interpretación de los preceptos constitucionales, para evitar lo más posible la discrecio-

219 Contemplado expresamente en el art. 98 de la constitución de Ecuador. Sobre el tema véase Noguera, "What do we mean when we talk about 'Critical Constitutionalism'?”, cit.

220 En ese sentido sin duda el caso boliviano es el ejemplo más rotundo de transformación institucional, en cuanto avanza hacia un Estado plurinacional, con un Tribunal Constitucional plurinacional elegido directamente por la ciudadanía. Véase Viciano y Martínez, cit., p. 35. En contra de esta afirmación, Salazar, "El nuevo constitucionalismo latinoamericano", cit, pp. 370 y 371 .

221 Pisarello, op. cit., p. 2.

222 Constitución de Bolivia: artículo 199.II, en la Constitución de Venezuela: artículo 264.

223 Constitución de Bolivia artículo 198. 
Esta revista forma parte del acervo de la Biblioteca Jurídica Virtual del Instituto de Investigaciones Jurídicas de la UNAM www.juridicas.unam.mx

http://biblio.juridicas.unam.mx

ANA MICAELA ALTERIO

nalidad judicial,224 cuales son el tenor literal del texto, la voluntad del constituyente, asi como la integralidad de la constitución. 225 Por último se otorga amplio acceso de la ciudadanía a los tribunales e incluso la legitimación activa universal para la presentación del recurso de inconstitucionalidad. 226

De todos modos, este tipo de diseños genera una fuerte tensión al interior del modelo en estudio que es advertida por casi la unanimidad de la academia. Es que es dificil pensar en el establecimiento de modelos de justicia constitucional fuerte que al tiempo, pretendan una participación amplia de los movimientos sociales y la ciudadanía en general para la determinación del contenido constitucional.227 Esa conciliación parece ser la aspiración del nuevo constitucionalismo latinoamericano, aunque habrá que ver en la práctica si es viable.

Otra nota de originalidad en este aspecto surge de la implementación de nuevas funciones y poderes del Estado

224 Aunque es cierto que, como advierte Salazar en su crítica, debido a la extensión del articulado y la gran variedad de tradiciones, ideologías y cosmovisiones que recogen, los documentos constitucionales en estudio se prestan a las más diversas interpretaciones, que en suma, quedan en manos de los jueces. Salazar, "El nuevo constitucionalismo latinoamericano”, cit., pp. 356, 360. Lo mismo, sin ser crítico, señala Pazmiño, op. cit., p.45: “...existe la tendencia a que sean los jueces, y no el Parlamento o el Gobierno, los que asumen el rol fundamental en la creación del Derecho por medio de su función de intérpretes de la Constitución".

225 Artículos 196.II de la Constitución de Bolivia y artículo 427 de la Constitución de Ecuador.

226 Véase Noguera, Albert "Las nuevas Constituciones andinas y la articulación democrática entre justicia constitucional, conflicto y transacción social", en Alterio y Niembro, Constitucionalismo popular en Latinoamérica, cit., p. 178; resaltando que el hecho de que los ciudadanos puedan participar en el planteamiento de acciones de inconstitucionalidad ante las cortes, determina el carácter más popular de la justicia constitucional, p. 172 .

227 Salazar, "El nuevo constitucionalismo latinoamericano", cit., pp. 376-381. Gargarella, Roberto, "Pensando sobre la reforma constitucional en América Latina”, en Rodríguez Garavito, César (coord.), El derecho en América Latina, cit., p. 97. Uprimny, cit., pp. 131-133. 
Esta revista forma parte del acervo de la Biblioteca Jurídica Virtual del Instituto de Investigaciones Jurídicas de la UNAM www.juridicas.unam.mx

http://biblio.juridicas.unam.mx

CONSTITUCIONALISMO CONTEMPORÁNEO A DEBATE

que se apartan de la tripartición liberal clásica. En este sentido se crean "el Poder Electoral y un Poder ciudadano de control ('cuarto poder'), que toma el nombre de 'Poder Ciudadano' en la constitución de Venezuela (título V, capítulo IV), 'Poder de Transparencia y Control social' en la ecuatoriana de 2008 (capítulo quinto, título IV, 'Participación y organización del poder'), y función de 'Participación y control social' en la boliviana de 2009 (artículos 241 y 242)". 228 Esto genera una complejidad institucional ${ }^{229}$ que puede aparejar cierta fragilidad, puesto que muchas de las instituciones no han sido probadas con anterioridad y por tanto, no se puede saber qué grado de utilidad o problemas vayan a tener. ${ }^{230}$

Por último aunque no menos importante, destacan en las nuevas constituciones apartados dedicados a la relación entre Estado y economia, con un fuerte protagonismo del primero, al punto que se habla de "constituciones dirigis-

228 Noguera, "Las nuevas constituciones andinas y la articulación democrática entre justicia constitucional, conflicto y transacción social", cit., p. 17. Como explica el autor: "Se trata, sobre todo en el caso de Ecuador, de un órgano de contra-poder, conformado por representantes de la sociedad civil, contra las decisiones del gobierno, aunque en la práctica, la intromisión del gobierno en el proceso de nombramiento de sus miembros haya mermado sus potencialidades de control y enfrentamiento contra el Poder".

229 Salazar, "El nuevo constitucionalismo latinoamericano", cit., p. 356. Que no complejidad lingüística, "debido a la voluntad de trascender el constitucionalismo de élites hacia un constitucionalismo popular". Viciano y Martínez, cit., especialmente p. 41. Esto último es importante en contraste con la aludida sofisticación que ha desarrollado el neoconstitucionalismo en materia de interpretación constitucional.

230 Viciano y Martínez, cit., p. 39. También Gargarella, "El nuevo constitucionalismo latinoamericano", cit., p. 18, advierte sobre las dificultades para diseñar obras de macro-ingeniería, dado que son demasiadas las consecuencias no intencionadas que no podemos prever ni controlar. Una crítica fuerte al abandono de la ortodoxa separación de poderes, consultable en Couso, Javier, "Las democracias radicales y el nuevo constitucionalismo latinoamericano", disponible en http://www.law.yale.edu/docu ments/pdf/sela/SELA13_Couso_CV_Sp_20130420.pdf, p. 21. 
Esta revista forma parte del acervo de la Biblioteca Jurídica Virtual del Instituto de Investigaciones Jurídicas de la UNAM www.juridicas.unam.mx

http://biblio.juridicas.unam.mx

ANA MICAELA ALTERIO

tas"231 y de "gobierno económico".232 Esta intervención estatal en la economia, por un lado se desmarca abiertamente de los tipos (neo)liberales de Estado y de la concepción capitalista de mercado que los acompaña. ${ }^{233}$ Por otro lado, tiene por fin hacer efectivos los objetivos de igualdad material entre las personas y grupos que tienen estas constituciones latinoamericanas ${ }^{234}$ y el respeto al medio ambiente. Ambas cuestiones, siguen la lógica participativa ya aludida. Así, destacan instancias de atención ciudadana, instituciones de autogestión, cogestión, cooperativas, cajas de ahorro, empresas comunitarias y demás formas asociativas guiadas por los valores de mutua cooperación y solidaridad". ${ }^{235}$ E1 fortalecimiento de este proyecto, se confia simultáneamente al reforzamiento de la unidad latinoamericana y la autonomía en las relaciones internacionales. ${ }^{236}$

\section{3. ¿Qué teoría de la democracia?}

Resulta fundamental dilucidar a qué teoria de la democracia responde el nuevo constitucionalismo latinoamericano ya que allí descansa toda su legitimidad. Éste es claro al autodefinirla como "democracia participativa" 237 y como vimos, instrumenta los mecanismos vinculantes para que di-

231 Uprimny, cit., p. 127.

232 Maestro Buelga, Gonzalo, "El nuevo constitucionalismo económico latinoamericano", en Storini y Alenza (dirs.), Materiales sobre neoconstitucionalismo y nuevo constitucionalismo latinoamericano, cit., p. 93.

233 Como también se diferencia del constitucionalismo social de tipo europeo, aun cuando pueden encontrarse elementos comunes. Ibidem, pp. 86- 88, 90. Se habla así de tendencias anticapitalistas y anticoloniales: De Sousa Santos, op. cit., p. 85; en igual sentido Uprimny, cit., p. 116.

234 Viciano y Martínez, op. cit., pp. 48 y 49.

235 Artículo 70 de la Constitución de Venezuela.

236 Pisarello, op. cit., pp. 2, 15.

237 En la Constitución de Venezuela de 1999: preámbulo y artículos 6o., 18, 55, 62, entre otros. En la Constitución de Bolivia, artículo 11. En la constitución de Ecuador, se habla de "Participación en democracia" en el título IV, capítulo primero, sección tercera. 
Esta revista forma parte del acervo de la Biblioteca Jurídica Virtual del Instituto de Investigaciones Jurídicas de la UNAM www.juridicas.unam.mx

http://biblio.juridicas.unam.mx

CONSTITUCIONALISMO CONTEMPORÁNEO A DEBATE

cho adjetivo tenga sentido, incluidos mecanismos de democracia directa. Pero más allá de esa calificación, quisiera indagar un poco en el trasfondo de la propuesta.

Hay acuerdo en que la democracia participativa no cuestiona la esencia del sistema de democracia representativa, sino que se configura como un complemento. 238 Ahora bien, a mi criterio dos concepciones subyacen con fuerza a este modelo de democracia y otra asoma latente ante el eventual fracaso de estos ideales.

En primer lugar, una llamada a tipos de democracia radical 239 o "agonista". ${ }^{240}$ Así, muchos teóricos del nuevo constitucionalismo no dudan en basar su apoyo a esta corriente en su "crítica a la democracia liberal, y especialmente a algunos de sus presupuestos centrales como la asunción de que la sociedad es culturalmente homogénea, que el conflicto social se puede superar, y que las relaciones de poder sociales no juegan, o no deberían jugar, ningún papel en un esquema democrático de organización política". ${ }^{241}$ Para el modelo agonista, poder y legitimidad están inevitablemente vinculados. ${ }^{242}$ Esta concepción ha sido pasible de importantes críticas, especialmente destaca la que la acusa de provocar un colapso de la idea de legitimidad, en tanto no permite construir ningún criterio independiente de las pre-

238 Viciano y Martínez, op. cit., p. 45.Para otros autores es una "superación", véase Castro Riera, Carlos "Valoración jurídico-politica de la Constitución de 2008", p. 116 y Noguera Fernández, Albert, "Participación, función electoral y función de control y transparencia social”, p. 137, ambos en Ávila Santamaría, Ramiro et al. (eds.), Desafios constitucionales. La constitución ecuatoriana del 2008 en perspectiva, Quito, Ministerio de Justicia y Derechos Humanos, 2008.

239 Según Salazar, "El nuevo constitucionalismo latinoamericano", cit., p. 384. También para Couso, Javier, op. cit.

240 Según la caracterización de Mouffe, Chantal, La paradoja democrática. El peligro del consenso en la política contemporánea, 2a. ed., Barcelona, Gedisa, 2012.

241 Según lo que Martí, José Luis, La república deliberativa, cit., p. 71 considera los puntos en los que coinciden los defensores de la democracia agonista o radical.

242 Ibidem, p. 73. 
Esta revista forma parte del acervo de la Biblioteca Jurídica Virtual del Instituto de Investigaciones Jurídicas de la UNAM www.juridicas.unam.mx

http://biblio.juridicas.unam.mx

ANA MICAELA ALTERIO

ferencias de los individuos. ${ }^{243}$ Una crítica que nos vuelve a llevar al dificil equilibrio entre las ideas sustancialistas y procedimentales para sustentar la legitimidad.

En segundo lugar - $-\mathrm{y}$ en muchos casos de forma concomitante- se habla de modelos de democracia deliberativa, ${ }^{244}$ aunque no de tipo liberal, como expliqué puede hallarse en las corrientes neoconstitucionalistas, sino en clave republicana. Esto puesto que el nuevo constitucionalismo latinoamericano pone énfasis en "la esfera pública", las condiciones materiales para el funcionamiento de la democracia, ${ }^{245}$ la apertura e inclusión en la deliberación, etc.; rasgos que hacen pensar en un modelo deliberativo alternativo tanto al liberal como al comunitarista y que algunos de sus defensores califican de "modelo crítico". ${ }^{246}$ Con la misma idea se destacan la emergencia y reconstrucción de sujetos colectivos y el establecimiento de mecanismos de participación y confrontación para que esos sujetos utilicen en y contra el Estado. ${ }^{247}$ Como ya habrá notado el o la lectora, en este aspecto son evidentes las similitudes que se encuentran con los postulados del constitucionalismo popular. ${ }^{248}$

Otros autores, de un modo más ambicioso (y sustantivo), aluden a una democracia "intercultural", que sería aquella en la que coexisten a) diferentes formas de deliberación de-

243 Ibidem, pp. 74 y 75.

244 "La democracia deliberativa es siempre la condición sine qua non de la democracia participativa. Así como es, también, el imperativo esencial de una democracia representativa". Palacios, op. cit., p. 173.

245 En ese sentido se habla también de democracia "material". Viciano y Martínez, cit., p. 37.

246 Forst, op. cit., pp. 181, 183, 186.

247 Noguera, "What do we Mean when we Talk about "Critical Constitutionalism»?", cit., p. 105.

248 Aunque podría hallarse una diferencia en el hecho que el nuevo constitucionalismo latinoamericano apela al pueblo en tanto "soberano" y no mediado por el parlamento, cuya actuación "debe estar siempre limitada por el principio de la soberanía popular". Noguera, "Participación, Función Electoral y Función de Control y Transparencia Social”, cit., p. 147 , lo que en el constitucionalismo popular no es tan claro. 
Esta revista forma parte del acervo de la Biblioteca Jurídica Virtual del Instituto de Investigaciones Jurídicas de la UNAM www.juridicas.unam.mx

http://biblio.juridicas.unam.mx

CONSTITUCIONALISMO CONTEMPORÁNEO A DEBATE

mocrática —demodiversidad-, b) diferentes criterios de representación democrática, c) reconocimiento de derechos colectivos de los pueblos como condición de efectivo ejercicio de los derechos individuales, d)reconocimiento de nuevos derechos fundamentales (como derecho al agua, a la tierra, a la soberanía alimentaria, a los recursos naturales, etcétera) y e) educación orientada a formas de sociabilidad y de subjetividad asentadas en la reciprocidad cultural. ${ }^{249}$ Este tipo de democracia es incluso calificada como "una de las formulaciones constitucionales sobre democracia más avanzadas del mundo", ${ }^{250}$ aunque desde mi perspectiva podría considerarse una profundización de la democracia deliberativa de tipo critica.

Ahora bien, muchas disfuncionalidades de estos modelos hacen que nos planteemos el riesgo de una deriva hacia tipos de democracia populista ${ }^{251}$ o de "cesarismo democrático". ${ }^{252}$ Me refiero a la advertencia sobre la apelación recurrente a la consulta popular, estableciendo una "relación directa entre el líder y las masas" 253 que obvia otros canales participativos más deliberativos y por ello, mucho más "robustos" en términos democráticos. Aunado a un desmedido protagonismo del liderazgo presidencial, que amenaza la profundización democrática en tanto debilita los contrapesos institucionales, restringe la auto-organización popular y hace peligrar la participación y el pluralismo politico y social, ${ }^{254}$ lo que podría reforzar tendencias autoritarias en la región y convertir a la democracia participativa en una

249 Santos, op. cit., pp. 118 y 119 , afirmando que es el tipo de democracia consagrada en las Constituciones de Ecuador y Bolivia.

250 Ibidem, p. 119. En igual sentido Uprimny, cit., p. 124.

251 Salazar, "El nuevo constitucionalismo latinoamericano", cit., p. 384.

252 Uprimny, cit., p. 131.

253 Edwards, S., Populismo o mercados. El dilema de América Latina, Bogotá, Norma, 2009, p. 233, citado por Viciano y Martínez, cit., p. 23.

254 Pisarello, op. cit., pp. 16 y 17. Sobre lo mismo viene insistiendo Gargarella, "Pensando sobre la reforma constitucional en América Latina", cit., pp. 98-100 y "El nuevo constitucionalismo latinoamericano: promesas e interrogantes", cit., p. 11. 
Esta revista forma parte del acervo de la Biblioteca Jurídica Virtual del Instituto de Investigaciones Jurídicas de la UNAM www.juridicas.unam.mx

http://biblio.juridicas.unam.mx

ANA MICAELA ALTERIO

mera ilusión. ${ }^{255} \mathrm{El}$ sortear estos riesgos es uno de los desafíos que enfrenta la región y que debe guiar la arquitectura institucional del nuevo constitucionalismo latinoamericano.

\section{La relación entre derecho y politica}

Por último cabe detenerse en la fuerte relación entre derecho y politica presente en el nuevo constitucionalismo latinoamericano, que se preocupa no sólo por la dimensión jurídica de la constitución sino, incluso en primer orden, por la legitimidad democrática de la misma. En efecto, se afirma que "el primer problema del constitucionalismo democrático es servir de traslación fiel de la voluntad constituyente y establecer los mecanismos de relación entre la soberania... y la constitución". ${ }^{256}$ Este "fortalecimiento de la dimensión política" de la constitución también se ve reflejado en su carga simbólica. ${ }^{257}$

Para respetar el análisis hecho con las corrientes anteriores, diré que desde el punto de vista interno esa relación es ambigua. De un lado, encontramos una amplísima consagración de derechos, en términos de principios que requieren una concreción por parte de los poderes políticos y para la cual está prevista una fuerte participación ciudadana. En ese sentido no cabe duda de que los significados constitucionales serán pasibles de disputa "politica", ${ }^{258}$ máxime para la puesta en práctica de los proyectos de país enuncia-

\footnotetext{
255 Uprimny, cit., p. 131. También Couso, op. cit., pp. 11-12.

256 Viciano y Martínez, cit., p. 20.

257 Ibidem, p. 37.

258 Salazar, "El nuevo constitucionalismo latinoamericano", cit., p. 364.
} Así nos advierte Salazar sobre la escaza utilidad del nuevo constitucionalismo latinoamericano como herramienta para superar los conflictos sociales, pues por el contrario, la constitución "se convierte en una de las causas de los mismos porque la disputa política anterior a la Constitución se ha trasladado al seno de la misma”. 
Esta revista forma parte del acervo de la Biblioteca Jurídica Virtual del Instituto de Investigaciones Jurídicas de la UNAM www.juridicas.unam.mx

http://biblio.juridicas.unam.mx

CONSTITUCIONALISMO CONTEMPORÁNEO A DEBATE

dos con carácter normativo. ${ }^{259}$ Pero sobre el punto se nos recuerda que:

...los textos constitucionales, sobre todo cuando son el resultado de procesos participativos intensos, no son simples instrumentos técnicos pensados para obedecer a las exigencias rigoristas del jurista. Son también, y ante todo, documentos políticos, con una función legitimadora y pedagógica que no puede soslayarse. 260

Aunque de otro lado, la primacía del constituyente originario, reflejada tanto en los mecanismos de interpretación previstos constitucionalmente, como en las partes más "reglamentaristas" de las constituciones, rigidas, hace que se hable de una rigidez interpretativa al punto de "congelar" lo decidido en el momento constituyente contra cualquier natural evolución que se pudiera desarrollar. ${ }^{261}$

Más clara es la relación desde el punto de vista externo, pues el predominio absoluto de lo político sobre lo jurídico es evidente. No es necesario repetir lo ya analizado, sólo recordar la permanente apelación a la legitimidad (extrajurídica) ${ }^{262}$ de la constitución, invocando al constituyente revolucionario para ilustrarse las infinitas posibilidades que permanecen abiertas.

\section{PERTINENCia DE LA COMPARAción}

He intentado repasar las teorias que subyacen a las corrientes del neoconstitucionalismo, el constitucionalismo popular y los nuevos constitucionalismos latinoamericanos

259 En este sentido, la mayor parte de las reformas se proyectan hacia el futuro, pues "más que intentar codificar las relaciones de poder existentes, son documentos jurídicos que tienden a delinear un modelo de sociedad a construir. Son pues (...) Constituciones "aspiracionales»". Uprimny, op. cit., p. 123.

260 Pisarello, op. cit., p. 9, nota al pie núm. 14.

261 Véase Couso, op. cit., pp. 17 y 18.

262 Viciano y Martínez, cit., p. 20. 
Esta revista forma parte del acervo de la Biblioteca Jurídica Virtual del Instituto de Investigaciones Jurídicas de la UNAM www.juridicas.unam.mx

http://biblio.juridicas.unam.mx

ANA MICAELA ALTERIO

a fin de poder realizar una comparación que sirva para pensar normativamente en los modelos que queremos adoptar para nuestros países. Considero que la reflexión es pertinente dado la última ola de reformas que se ha dado en numerosos países de América Latina y lo pobres que han resultado ser sus contribuciones en términos de democratización, igualdad o justicia. ${ }^{263}$ En este sentido, no se pretende aquí propiciar un "modelo", sino tener en cuenta qué bases los animan a la hora de imaginar estructuras propias para nuestras realidades concretas.

Así, he elegido para analizar el neoconstitucionalismo por la enorme influencia que esta doctrina ha tenido en la región, ${ }^{264}$ así como por la adopción que se ha hecho de varias de sus propuestas, muchas veces sin reparar en las consecuencias que podian tener dentro del marco institucional en el que se incorporaban; de rasgos marcadamente elitistas. ${ }^{265}$ Un ejemplo claro en este sentido es la proliferación de derechos en las cartas fundamentales y a su vez la creación de Tribunales Constitucionales, medidas ambas que, como podrían advertir los populares, "amenazan con cercenar el espacio de la discusión democrática".266

Por otro lado, me ocupé del constitucionalismo popular en tanto voz "alternativa" dentro del constitucionalismo, que denuncia el elitismo de la disciplina dominante e intenta demostrar la posibilidad de cambios rotundos en su abordaje. Así coloca sobre la mesa temas como la integración de la ciudadanía a la esfera pública, la importancia de

263 Gargarella, "Pensando sobre la reforma constitucional en América Latina", cit., p. 87.

264 En palabras de Carbonell y García: hay "asentado consenso que la fenomenología abarcada por la corriente denominada "neoconstitucionalismo", ha ejercido un marcado influjo en diversos procesos institucionales, pedagógicos y jurisprudenciales en distintos países iberoamericanos" en Prólogo: "Desafíos y Retos del Canon Neoconstitucional", en Carbonell et al. (eds.), El canon neoconstitucional, cit., p. 11.

265 Gargarella, "Pensando sobre la reforma constitucional en América Latina", cit., p. 89.

266 Ibidem, p. 97. 
Esta revista forma parte del acervo de la Biblioteca Jurídica Virtual del Instituto de Investigaciones Jurídicas de la UNAM www.juridicas.unam.mx

http://biblio.juridicas.unam.mx

CONSTITUCIONALISMO CONTEMPORÁNEO A DEBATE

la igualdad y de la democratización de las instituciones, el estatuto político del derecho, etcétera; temas todos que han sido "bandera" - al menos en la retórica- de las reformas latinoamericanas.

Finalmente quise hacer un repaso del nuevo constitucionalismo latinoamericano, sobre todo en tanto sí concretó reformas sustanciales en estos últimos sentidos, tomando con un cariz innovador, parte del legado de las dos corrientes anteriores. Uprimny se pregunta ${ }^{267}$ justamente si esta combinación entre formas de neoconstitucionalismo -que tienden a proteger la autonomía individual - junto a mecanismos de participación popular y democrática - que propenden a garantizar el autogobierno colectivo- no intenta configurar un nuevo modelo constitucional, de tipo igualitarista, superador tanto del pensamiento liberal, como del conservador y el radical presentes en los orígenes del constitucionalismo americano. ${ }^{268}$ La respuesta no es clara, pues si bien encontramos elementos alentadores en ese sentido, el nuevo constitucionalismo latinoamericano mantiene disposiciones que generan tensiones y problemas tanto en su interior como en su funcionamiento.

Mucho camino queda por recorrer, pero lo importante es mantener estos temas dentro de la agenda del constitucionalismo y por tanto dentro de la discusión política y académica, que por lo demás, siempre pretende ser "performativa" de la realidad.269 Seguramente lo peor que podemos hacer es considerar la materia "acabada" y los sistemas institucionales terminados, dedicándonos a justificar las estructuras vigentes. Por eso ésta pretende ser una pequeña contribución al debate sobre las múltiples posibilidades abiertas dentro de nuestra disciplina.

267 Uprimny, "Las transformaciones constitucionales recientes en América Latina: tendencias y desafios", op. cit., p. 132.

268 Según la clasificación de Gargarella, Roberto, Los fundamentos legales de la desigualdad. El constitucionalismo en América (1776-1860), Madrid, 2a. ed., Siglo XXI de España, 2008.

269 Ferrajoli, Principia Iuris, cit., t. I, pp. 31 y ss. 
Esta revista forma parte del acervo de la Biblioteca Jurídica Virtual del Instituto de Investigaciones Jurídicas de la UNAM www.juridicas.unam.mx http://biblio.juridicas.unam.mx

ANA MICAELA ALTERIO

VI. BIBLIOGRAFÍA

AGUILÓ REGLA, Josep, “Sobre las contradicciones (tensiones) del constitucionalismo y las concepciones de la constitución", en CARBONELL, Miguel y GARCÍA JARAMILLO, Leonardo (eds.), El canon neoconstitucional, Madrid, Trotta, 2010.

Ahumada, María Ángeles, "Neoconstitucionalismo y constitucionalismo", en COMANDUCCI, Paolo et al., Positivismo jurídico y neoconstitucionalismo, Madrid, Fundación Coloquio Jurídico Europeo, 2009.

ALEXY, Robert, "Sistema jurídico, principios jurídicos y razón práctica”, Doxa, núm. 5, 1988.

ALEXY, Robert, Teoría de los derechos fundamentales, trad. de Ernesto Garzón Valdés, Madrid, Centro de Estudios Constitucionales, 1993.

ALEXY, Robert, El concepto y la validez del derecho, 2a. ed., trad. de Jorge Malem Seña, Barcelona, Gedisa, 2004.

ALEXY, Robert, Teoría de la argumentación juridica: la teoría del discurso racional como teoría de la fundamentación jurídica, 2a. ed., trad. de Manuel Atienza e Isabel Espejo, Madrid, Centro de Estudios Políticos y Constitucionales, 2008.

ALTERIO, Ana Micaela, "La 'esfera de lo indecidible' en el constitucionalismo de Luigi Ferrajoli: un análisis crítico", Universitas. Revista de Filosofía, Derecho y Politica, núm. 13, enero de 2011.

ALTERIO, Ana Micaela, "El ius-constitucionalismo de Luigi Ferrajoli desde una mirada política" (comunicación), 1er Encuentro de Jóvenes Investigadores de la Sociedad Española de Filosofía Jurídica y Politica: Neoconstitucionalismo en tiempos de postdemocracia, Universitat de València, 25 de abril de 2012, diponible en http://www.uv.es/drets/Alterio_Micaela.pdf. 
Esta revista forma parte del acervo de la Biblioteca Jurídica Virtual del Instituto de Investigaciones Jurídicas de la UNAM www.juridicas.unam.mx

http://biblio.juridicas.unam.mx

CONSTITUCIONALISMO CONTEMPORÁNEO A DEBATE

ATIENZA, Manuel, El derecho como argumentación, Barcelona, Ariel, 2006.

ATIENZA, Manuel, "Argumentación y Constitución”, en AGUILÓ REGLA, Josep et al., Fragmentos para una teoría de la Constitución, Madrid, Iustel, 2007.

ATIEnZA, Manuel, "Imperio de la ley y Constitucionalismo. Un diálogo entre Manuel Atienza y Francisco Laporta”, El Cronista del Estado social y Democrático de derecho, núm. 0, 2008.

ATRIA, Fernando, "La ironía del positivismo jurídico", Doxa, núm. 27, 2004.

BALKIN, Jack M., "Populism and Progressivism as Constitutional Categories", Faculty Scholarship Series, Paper 268, 1995.

BALKIN, Jack M., "The Constitution of Status", The Yale Law Journal 106, 1996-1997.

BARBERIS, Mauro, "Neoconstitucionalismo, democracia e imperialismo de la moral" en CARBONELL, Miguel (ed.), Neoconstitucionalismo(s), Madrid, Trotta, 2003.

BAYÓN, Juan Carlos, "Derechos, Democracia y Constitución”, en CARBONELl, Miguel (ed.), Neoconstitucionalismo(s), Madrid, Trotta, 2003.

BAYÓN, Juan Carlos, "Democracia y derechos: problemas de fundamentación del constitucionalismo", en CARBONELL, Miguel y GARCÍA JARAMILLO, Leonardo (eds.), El canon neoconstitucional, Madrid, Trotta, 2010.

Bellamy, Richard, Constitucionalismo politico. Una defensa republicana de la constitucionalidad de la democracia, trad. de Jorge Urdánoz Ganuza y Santiago Gallego Aldaz, Madrid, Marcial Pons, 2010.

BoвBIO, Norberto, "La Regla de Mayoría: límites y aporías", en Bovero, Michelangelo (ed.), Teoría general de la politica, Madrid, Trotta, 2003. 
Esta revista forma parte del acervo de la Biblioteca Jurídica Virtual del Instituto de Investigaciones Jurídicas de la UNAM www.juridicas.unam.mx

http://biblio.juridicas.unam.mx

ANA MICAELA ALTERIO

CARBOnELL, Miguel, Neoconstitucionalismo y derechos fundamentales, Quito, Cevallos, 2010.

CARbonell, Miguel y García Jaramillo, Leonardo, Prólogo: "Desafíos y Retos del Canon Neoconstitucional", en CARBOnEll, Miguel y GARCÍA JARAMILlo, Leonardo (eds.), El canon neoconstitucional, Madrid, Trotta, 2010.

CASTRO RIERA, Carlos "Valoración jurídico-política de la Constitución de 2008", en Ávila SANTAMARÍA, Ramiro et al. (eds.) Desafios constitucionales. La Constitución ecuatoriana del 2008 en perspectiva, Quito, Ministerio de Justicia y Derechos Humanos, 2008, pp. 111-129.

COMANDUCCI, Paolo, "Formas de (neo)constitucionalismo: un análisis metateórico", en CARBONELL, Miguel (ed.), Neoconstitucionalismo(s), Madrid, Trotta, 2003.

COMANDUCCI, Paolo, "Constitucionalización y neoconstitucionalismo", en CoMANDUCCI, Paolo et al., Positivismo jurídico y neoconstitucionalismo, Madrid, Fundación Coloquio Jurídico Europeo, 2009.

Couso, Javier, "Las democracias radicales y el 'nuevo constitucionalismo latinoamericano", disponible en http://www.law.yale.edu/documents/pdf/sela/SELA13_Couso_CV_Sp_20130420.pdf.

COVER, Robert, "The Supreme Court, 1982 Term- Foreword: Nomos and Narrative", Harvard Law Review 97, 1983.

CRUZ, Luis M., Estudios sobre el neoconstitucionalismo, México, Porrúa, 2006.

DE LORA, Pablo, "Luigi Ferrajoli y el constitucionalismo fortísimo", en CARBOnEll, Miguel y SAlazAR, Pedro (eds.), Garantismo, Estudios sobre el pensamiento jurídico de Luigi Ferrajoli, Madrid, Trotta-UNAM, Instituto de Investigaciones Jurídicas, 2005. 
Esta revista forma parte del acervo de la Biblioteca Jurídica Virtual del Instituto de Investigaciones Jurídicas de la UNAM www.juridicas.unam.mx

http://biblio.juridicas.unam.mx

CONSTITUCIONALISMO CONTEMPORÁNEO A DEBATE

De sousa SAnTos, Boaventura, Refundación del Estado en América Latina. Perspectivas desde una epistemología del sur, México, Siglo XXI, Siglo del Hombre Editores, Universidad de los Andes, 2010.

Dussel, Enrique, "Hacia una filosofía política crítica", Bilbao, Desclée de brouwer, 2001.

DWORKIN, Ronald, "Rights as Trumps", en WALDRON, Jeremy (ed.), Theories of Rights, Nueva York, Oxford University Press, 1984.

DWORKIN, Ronald, “¿Realmente no hay respuesta correcta en los casos dificiles?", en CASANOVAS, Pompeu y MoRESo, Juan (eds.), El ámbito de los jurídico. Lecturas de pensamiento jurídico contemporáneo. Barcelona, Crítica, 1994.

DWORKIN, Ronald, "The Moral Reading and the Majoritarian Premise", Freedom's Law. The moral reading of the American Constitution, Oxford University Press, 1996.

Dworkin, Ronald, Los derechos en serio, trad. de Marta Guastavino, Barcelona, Ariel Derecho, 2002.

DWORKIN, Ronald, "La lectura moral y la premisa mayoritaria”, en HONGJU KOH, Harold y SLYE, Ronald (comp.), Democracia deliberativa y derechos humanos, Barcelona, Gedisa, 2004.

DWORKIN, Ronald, La democracia posible: principios para un nuevo debate politico, trad. de Ernest Weikert García, Barcelona, Paidós Ibérica, 2008.

ELSTER, Jon, Ulises y las sirenas. Estudios sobre racionalidad $e$ irracionalidad, trad. de Juan José Utrilla, México, Fondo de Cultura Económica, 1995.

ElSTER, Jon, (comp.), La democracia deliberativa, Barcelona, Gedisa, 2001.

ELSTER, Jon, Ulises desatado. Estudios sobre racionalidad precompromiso y restricciones, trad. de Jordi Mundó, Barcelona, Gedisa, 2002. 
Esta revista forma parte del acervo de la Biblioteca Jurídica Virtual del Instituto de Investigaciones Jurídicas de la UNAM www.juridicas.unam.mx

http://biblio.juridicas.unam.mx

ANA MICAELA ALTERIO

FERRAJOLI, Luigi, "Pasado y futuro del Estado de derecho", en CARBOnELl Miguel, (ed.) Neoconstitucionalismo(s), Madrid, Trotta, 2003.

FERRAJOLI, Luigi, Derechos y garantias. La ley del más débil, 5a. ed., trad. de Perfecto Andrés Ibáñez y Andrea Greppi, Madrid, Trotta, 2006.

FERRAJOLI, Luigi, Democracia y garantismo, edición de Miguel Carbonell, Madrid, Trotta, 2008.

FERRAJOLI, Luigi, "Costituzionalismo principialista e costitucionalismo garantista", Giurisprudenza costituzionale, vol. 55, núm. 3, Milán, Giuffrè, 2010.

Ferrajoli, Luigi, Principia Iuris. Teoria del derecho y de la democracia, trad. de Perfecto Andrés Ibáñez, Juan Carlos Bayón, Marina Gascón, Luis Prieto Sanchís y Alfonso Ruiz Miguel, t. I: Teoría del derecho; t. II: Teoría de la democracia y t. III: La sintaxis del derecho, Madrid, Trotta, 2011.

FERRAJOLI, Luigi y RUIZ MANERO, Juan, Dos modelos de constitucionalismo. Una conversación, Madrid, Trotta, 2012.

FORST, Rainer, "The Rule of Reasons. Three Models of Deliberative Democracy", Ratio Juris, vol. 14, núm. 4, diciembre de 2001.

FRIEDMAN, Barry, "Mediated Popular Constitutionalism", Michigan Law Review, vol. 101, 2003.

García FigueroA, Alfonso, Principios y positivismo jurídico. Madrid, Centro de Estudios Políticos y Constitucionales, 1998.

GARCía FigueroA, Alfonso, Criaturas de la Moralidad. Una aproximación neoconstitucionalista al Derecho a través de los derechos, Madrid, Trotta, 2009.

GARGARELLA, Roberto, "Los jueces frente al coto vedado", Doxa. Discusiones. Publicaciones periódicas, núm. 1, 2000. 
Esta revista forma parte del acervo de la Biblioteca Jurídica Virtual del Instituto de Investigaciones Jurídicas de la UNAM www.juridicas.unam.mx

http://biblio.juridicas.unam.mx

CONSTITUCIONALISMO CONTEMPORÁNEO A DEBATE

GARGARELLA, Roberto, "Acerca de Barry Friedman y el "constitucionalismo popular mediado"”, Revista Jurídica de la Universidad de Palermo, año 6, núm. 1, 2005.

GARGARELLA, Roberto, Los fundamentos legales de la desigualdad. El constitucionalismo en América (17761860), 2a. ed., Madrid, Siglo XXI de España, 2008.

GARGARELLA, Roberto, "Pensando sobre la reforma constitucional en América Latina", en RODRIGUEZ GARAVITO, Cesar (coord.), El derecho en América Latina. Un mapa para el pensamiento jurídico del siglo XXI, Buenos Aires, Siglo XXI, 2011, pp. 87-107. Disponible en www.igualitaria.org.

GARGARELLA, Roberto, "El nacimiento del constitucionalismo popular. Sobre The people Themselves, de Larry Kramer", disponible en www.juragentium.unifi.it/es/ surveys/latina/gargarel.pdf.

GARGARELLA, Roberto, "Una disputa imaginaria sobre el control judicial de las leyes. El 'constitucionalismo popular' frente a la teoría de Nino”, en CARBONELL, Miguel y GARCÍA JARAMILLO, Leonardo (eds.), El canon neoconstitucional, Madrid, Trotta, 2010.

GARGARELLA, Roberto, "El nuevo constitucionalismo latinoamericano: Promesas e interrogantes", disponible en http://www.palermo.edu/Archivos_content/derecho/ pdf/Constitucionalismo_atinoamericano.pd.

GARGARElla, Roberto, "Prólogo", en Alaterio, Ana Micaela y NIEMBRO ORTEGA, Roberto (coord.), Constitucionalismo popular en Latinoamérica, México, Porrúa, 2013, pp. XIII-XVI.

GARGARELlA, Roberto y MARTí, José Luis, "Estudio preliminar. La filosofia del derecho de Jeremy Waldron: convivir entre desacuerdos", en WALDRON, Jeremy, Derecho y Desacuerdos, traducción de José Luis Martí y Águeda Quiroga, Madrid, Marcial Pons, 2005. 
Esta revista forma parte del acervo de la Biblioteca Jurídica Virtual del Instituto de Investigaciones Jurídicas de la UNAM www.juridicas.unam.mx

http://biblio.juridicas.unam.mx

ANA MICAELA ALTERIO

GARZÓN VALDÉS, Ernesto, "Consenso, racionalidad y legitimidad" (1990), Derecho, ética y politica, Madrid, Centro de Estudios Politicos y Constitucionales, 1993.

GARZÓN VALDÉS, Ernesto, "La alternativa del disenso. La propuesta de Javier Muguerza", Derecho, ética y politica, Madrid, Centro de Estudios Politicos y Constitucionales, 1993.

GARZÓN VALDÉS, Ernesto, "El consenso democrático: Fundamento y limites del papel de las minorías", Isonomía, núm. 12, 2000.

GUASTINI, Ricardo, "La "constitucionalización" del ordenamiento jurídico: el caso italiano", en CARBONELL, Miguel (ed.), Neoconstitucionalismo(s), Madrid, Trotta, 2003.

Gutmann, Amy y Thompson, Dennis, Why Deliberative Democracy?, Princeton, Princeton University Press, 2004.

HABERMAS, Jürgen, Facticidad y validez sobre el derecho y el Estado democrático de derecho en términos de teoría del discurso, 5a. ed., trad. de Manuel Jiménez Redondo, Madrid, Trotta, 2008.

KRAMER, Larry, "Popular Constitutionalism, circa 2004", California Law Review, vol. 92, núm. 4, 2004.

KRAMER, Larry, The people themselves. Popular Constitutionalism and Judicial Review, New York, Oxford University Press, 2004.

KRAMER, Larry, "Undercover Anti-Populism", Fordham Law Review 73, 2005.

LEVInson, Sanford, Constitutional Faith, Princeton University Press, 1988.

LINARES, Sebastián, La (i)legitimidad democrática del control judicial de las leyes, Madrid, Marcial Pons, 2008. 
Esta revista forma parte del acervo de la Biblioteca Jurídica Virtual del Instituto de Investigaciones Jurídicas de la UNAM www.juridicas.unam.mx

http://biblio.juridicas.unam.mx

CONSTITUCIONALISMO CONTEMPORÁNEO A DEBATE

Maestro Buelga, Gonzalo, "El nuevo constitucionalismo económico latinoamericano", en STORINI, Claudia y AlEnZA GARCÍA, José Francisco (dirs.), Materiales sobre neoconstitucionalismo y nuevo constitucionalismo latinoamericano, Navarra, Aranzadi, 2012.

MARTí, José Luis, La república deliberativa. Una teoría de la democracia. Madrid, Marcial Pons, 2006.

MARTí, José Luis, "Un callejón sin salida. La paradoja de las precondiciones (de la democracia deliberativa) en Carlos S. Nino", en ALEGRE, Marcelo et al. (coords.), Homenaje a Carlos S. Nino, Buenos Aires, La Ley, 2008.

Moreno Rodríguez AlCALÁ, Diego, Control judicial de la ley $y$ derechos fundamentales. Una perspectiva critica, Madrid, Centro de Estudios Politicos y Constitucionales, 2011.

Mouffe, Chantal, La paradoja democrática. El peligro del consenso en la política contemporánea, 2a. ed., Barcelona, Gedisa, 2012.

NIEMBRO ORTEGA, Roberto, “¿Qué es el constitucionalismo popular? Una breve referencia al uso de las fuerzas armadas en México como fuerzas de seguridad", en Alterio, Ana Micaela y NIEMBRo ORTEGA, Roberto (coords.), Constitucionalismo popular en Latinoamérica, México, Porrúa, 2013.

Nino, Carlos Santiago, La constitución de la democracia deliberativa, trad. de Roberto Saba, Barcelona, Gedisa, 2003.

NOGUERA FERNÁNDEZ, Albert, "Participación, función electoral y función de control y transparencia social", en Ramiro Ávila SANTAMARÍA et al. (eds.), Desafios constitucionales. La Constitución ecuatoriana del 2008 en perspectiva, Quito, Ministerio de Justicia y Derechos Humanos, 2008. 
Esta revista forma parte del acervo de la Biblioteca Jurídica Virtual del Instituto de Investigaciones Jurídicas de la UNAM www.juridicas.unam.mx http://biblio.juridicas.unam.mx

ANA MICAELA ALTERIO

Noguera FERnÁNDEZ, Albert, "What do We Mean When We Talk About "Critical Constitutionalism?" Some Reflections on the New Latin American Constitutions", en NOLTE, Detlef y Schilling-VACAFLOR, Almut (eds.), New Constitutionalism in Latin America. Promises and Practices, England, Ashgate, 2012.

NOGUERA FERNÁNDEZ, Albert, "Las nuevas constituciones andinas y la articulación democrática entre justicia constitucional, conflicto y transacción social”, en Alterio, Ana Micaela y Niembro ORTEGA, Roberto, Constitucionalismo popular en Latinoamérica, México, Porrúa, 2013.

NOLTE, Detlef y SCHILLING- VACAFLOR, Almut, "Introduction: The Times they are a Changin': Constitutional Transformations in Latin America since the 1990s", en NolTE, Detlef y Schilling-VACAFlor, Almut (eds.), New Constitutionalism in Latin America. Promises and Practices. England, Ashgate, 2012.

PAlacios Romeo, Francisco, "La reivindicación de la polis: crisis de la representación y nuevas estructuras constitucionales de deliberación y participación en Latinoamérica", en STORINI, Claudia y ALENZA GARCÍA, José Francisco (dirs.), Materiales sobre neoconstitucionalismo y nuevo constitucionalismo latinoamericano, Navarra, Aranzadi, 2012.

PARKER, Richard, "Here, The People Rule: A Constitutional Populist Manifiesto", Valparaiso University Law Review, vol. 27, núm. 3, 1993.

PAZMIÑO FREIRE, Patricio, "Algunos elementos articuladores del nuevo constitucionalismo latinoamericano", Cuadernos Constitucionales de la Cátedra Fadrique Furió Cerol, núm. 67/68.

PÉREZ CALVO, Alberto, "Características del nuevo constitucionalismo latinoamericano", en STORINI, Claudia y Alenza García, José Francisco (dirs.), Materiales so- 
Esta revista forma parte del acervo de la Biblioteca Jurídica Virtual del Instituto de Investigaciones Jurídicas de la UNAM www.juridicas.unam.mx

http://biblio.juridicas.unam.mx

CONSTITUCIONALISMO CONTEMPORÁNEO A DEBATE

bre neoconstitucionalismo y nuevo constitucionalismo latinoamericano, Navarra, Aranzadi, 2012.

PISARELlO, Gerardo, "El nuevo constitucionalismo latinoamericano y la Constitución venezolana de 1999", disponible en http://www.rebelion.org/docs/96201.pdf.

POST, Robert y SIEGEL, Reva, "Protecting the Constitution from the People: Juricentric Restrictions on Section Five Power", Indiana Law Journal 78, 2003.

Post, Robert y SiEgEL, Reva, "Popular Constitutionalism, Departamentalism, and Judicial Supremacy", California Law Review 92, 2004.

POST, Robert y SIEGEL, Reva, "Roe Rage: Democratic Constitutionalism and Backlash", Harvard Civil-Rights Civil-Liberties Law Review 42, 2007.

Post, Robert y SIEGEL, Reva, "Democratic Constitutionalism”, en BALKIn, Jack M. y SiEgEL, Reva (eds.), The Constitution in 2020, Nueva York, Oxford University Press, 2009.

POST, Robert, "Theorizing Disagreement: Reconceiving the Relationship Between Law and Politics", California Law Review 98, 2010.

Pozzolo, Susanna, "Metacritica del neocostituzionalismo. Una risposta ai critici di "Neocostituzionalismo e positivismo giuridico"”, Diritto \& Questioni Pubbliche, núm. 3, 2003.

Pozzolo, Susanna, "Un constitucionalismo ambiguo", en CARBonell, Miguel (ed.), Neoconstitucionalismo(s), Madrid, Trotta, 2003.

PRIETO SANCHÍs, Luis, Justicia constitucional y derechos fundamentales, Madrid, Trotta, 2003.

PRIETO SANCHÍS, Luis, "Neoconstitucionalismo y ponderación judicial", en CARBONELL, Miguel (ed.), Neoconstitucionalismo(s), Madrid, Trotta, 2003. 
Esta revista forma parte del acervo de la Biblioteca Jurídica Virtual del Instituto de Investigaciones Jurídicas de la UNAM www.juridicas.unam.mx http://biblio.juridicas.unam.mx

ANA MICAELA ALTERIO

PRIETO SANCHÍs, Luis, "El constitucionalismo de los Derechos", Teoría del Neoconstitucionalismo. Ensayos escogidos, Madrid, Trotta-UNAM, Instituto de Investigaciones jurídicas, 2007.

PRIETO SANCHÍs, Luis, "Principia iuris: una teoría del derecho no (neo) constitucionalista para estado constitucional", Doxa, Cuadernos de Filosofía del Derecho, Madrid, núm. 31, Marcial Pons, 2008.

PRIETO VALDÉS, Martha, "El nuevo constitucionalismo latinoamericano: nuevos paradigmas politico constitucionales", en VICIANO PASTOR, Roberto (ed.), Estudios sobre el nuevo constitucionalismo latinoame- ricano, Valencia, Tirant Lo Blanch, 2012.

RodrígueZ GARAVITO, César, "Prólogo. Teorías de retaguardia: la refundación del Estado, el derecho y la teoría social en América Latina", en SANTOS, Boaventura de Sousa, Refundación del Estado en América Latina. Perspectivas desde una epistemología del sur, México, Siglo XXI, Siglo del Hombre Editores, Universidad de los Andes, 2010.

Ruiz Miguel, Alfonso, "Lo no deliberable de la democracia deliberativa", Diritto \& Questioni Pubbliche, núm.9, 2009.

SAlazAR UGARTe, Pedro, La democracia constitucional. Una radiografía teórica, México, Fondo de Cultura Económica-UNAM, Instituto de Investigaciones Jurídicas, 2006.

SAlaZAR UGARTE, Pedro, "El nuevo constitucionalismo latinoamericano (una perspectiva crítica)", en GONZÁLEZ PÉREZ, Luis Raúl y VALADÉs Diego (coords.), El constitucionalismo contemporáneo. Homenaje a Jorge Carpizo, México, UNAM, 2013, disponible en http://biblio.juridicas.unam.mx/libros/7/3271/22.pdf. 
Esta revista forma parte del acervo de la Biblioteca Jurídica Virtual del Instituto de Investigaciones Jurídicas de la UNAM www.juridicas.unam.mx

http://biblio.juridicas.unam.mx

CONSTITUCIONALISMO CONTEMPORÁNEO A DEBATE

TushnET, Mark, Taking the Constitution Away from the Courts, Princeton, New Jersey, Princeton University Press, 1999.

TUSHNET, Mark, "Forms of Judicial Review as Expressions of Constitutional Patriotism", Law and Philosophy 22, Netherlands, 2003.

TUSHNET, Mark, "New Forms of Judicial Review and the persistence of Rights-and Democracy- Based Worries", Wake Forest Law Review, núm. 38, 2003.

Tushnet, Mark, "Popular Constitutionalism as Political Law”, Chicago Kent Law Review 81, 2006.

TUSHNET, Mark, "Prefacio", en Alterio, Ana Micaela y Niembro Ortega, Roberto (coords.), Constitucionalismo popular en Latinoamérica, en prensa.

UPRIMNY, Rodrigo, "Las transformaciones constitucionales recientes en América Latina: tendencias y desafios", en RoDRÍGUEZ GARAVITO, César (coord.), El derecho en América Latina. Un mapa para el pensamiento jurídico del Siglo XXI, Buenos Aires, Siglo XXI, 2011, disponible en www.igualitaria.org.

Viciano PAstor, Roberto y MARTínez DALMAU, Rubén, "Fundamento teórico del nuevo constitucionalismo latinoamericano", en VICIANO PASTOR, Roberto (ed.), Estudios sobre el nuevo constitucionalismo latinoamericano, Valencia, Tirant Lo Blanch, 2012.

VILlABElla ARMENGOL, Carlos Manuel, "El derecho constitucional del siglo XXI en Latinoamérica: un cambio de paradigma", en VICIANO PASTOR, Roberto (ed.), Estudios sobre el nuevo constitucionalismo latinoamericano, Valencia, Tirant Lo Blanch, 2012.

WALDRON, Jeremy, "The Core of the Case Against Judicial Review", The Yale Law Journal 115, 2006. 
Esta revista forma parte del acervo de la Biblioteca Jurídica Virtual del Instituto de Investigaciones Jurídicas de la UNAM

WALDRON, Jeremy, "A Right-Based Critique of Constitutional Rights", Oxford Journal of Legal Studies, vol. 13, núm. 1, Oxford University Press, 1993.

WALDRON, Jeremy, "Deliberación, desacuerdo y votación", en HongJU KoH, Harold y Slye, Ronald (comp.), Democracia deliberativa y derechos humanos, Barcelona, Gedisa, 2004.

WALDRON, Jeremy, Derecho y desacuerdos, trad. de José Luis Martí y Águeda Quiroga, Madrid, Marcial Pons, 2005.

WALDRON, Jeremy, "Constitutionalism: A Skeptical View", New York University Public Law and Legal Theory Working Papers, Paper 248, 2012.

ZAGREBELSKY, Gustavo, "Jueces constitucionales", en CARBONELL, Miguel (ed.), Teoría del neoconstitucionalismo. Ensayos escogidos, Madrid, Trotta, 2007.

ZAGREBELSKY, Gustavo, El derecho dúctil. Ley, derechos, justicia, 8a. ed., trad. de Marina Gascón, Madrid, Trotta, 2008.

ZURN, Christorpher F., "Deliberative Democracy and Constitutional Review", Law and Philosophy, núm. 21, Kluwer Law International, 2002. 